\title{
Anotações sobre forma musical e três técnicas motívico- temáticas de Schoenberg, desdobramento motívico, variação progressiva e prosa musical
}

\author{
Notes on Musical Form and Three Motivic-Thematic Techniques by \\ Schoenberg, Motivic Unfolding, Developing Variation, and Musical Prose
}

\author{
Norton Dudeque \\ Universidade Federal do Paraná
}

\begin{abstract}
Resumo: Este texto discute três distintas percepções analítico-musicais do compositor Arnold Schoenberg, como apresentado em seus textos e discutido na literatura pertinente ao assunto. Inicialmente, discute-se noções gerais sobre forma musical e questões de lógica, coerência e unidade em música. Após esta introdução, inicia-se com o tema principal deste texto: a abordagem motívica de Schoenberg. Desdobramento motívico, variação progressiva e prosa musical são, cada qual, uma possibilidade analítica e composicional distinta. Schoenberg sugere que estas abordagens possam ser relacionadas a determinados gêneros musicais de épocas específicas. No entanto, ao aplicar algumas destas noções a obras que não pertencem ao cânone Schoenberguiano, sugiro a validade analítica destas abordagens para outros repertórios.
\end{abstract}

Palavras-chave: Schoenberg. Análise musical. Desdobramento motívico. Variação progressiva. Prosa musical.

\begin{abstract}
This text discusses three distinct musical-analytical perceptions of the composer Arnold Schoenberg, as presented in his texts and discussed in the literature relevant to the subject. Initially, I discuss general notions about musical form and matters of logic, coherence and on unity in music. After this introduction, I present the main topic of this text: Schoenberg's motivic approach. Motive unfolding, developing variation and musical prose are, each, distinct analytical and compositional perspective. Schoenberg suggests that these approaches may be related to certain period specific musical genres. However, by applying some of these notions to works that are not part of the Schoenberguian canon, I suggest analytical validity of these approaches for other repertoires.
\end{abstract}

Keywords: Schoenberg. Music analysis. Unfolding. Developing variation. Musical prose. 


\section{Introdução}

Para assegurar a coerência de sua música atonal Schoenberg viu-se compelido a criar princípios formais adequados ao seu pensamento composicional. Para ele, o mais importante destes princípios é o motívico, que é entendido como capaz de prover a lógica e a coerência necessárias na criação de grandes formas musicais livres da sintaxe e da tonalidade tradicional. De fato, a coerência e a compreensibilidade, que são tão importantes para Schoenberg, dependem de um princípio de semelhança e reconhecimento do motivo musical. Esta ideia é a base da noção de Grundgestalt (gestalt básica) que é definida por Schoenberg como: "gestaltes que (possivelmente) ocorrem repetidamente dentro de uma peça inteira e às quais gestaltes derivadas podem ser relacionadas" (Schoenberg 1995, p. 169). Juntamente com esta noção, Schoenberg cunhou uma série de conceitos originais que almejavam elucidar e avaliar criticamente o discurso musical; estes conceitos têm como objetivo explicar a continuidade musical e a conexão de ideias musicais. Finalmente, a interação destas noções e da noção de Grundgestalt podem ser percebidas como parte de um processo maior de desenvolvimento motívico: o princípio da variação progressiva.

Em Fundamentos da Composição Musical Schoenberg declara que:

Forma significa que uma peça é "organizada", isto é, que ela é constituída de elementos que funcionam tal como um organismo vivo...Os requisitos essenciais para a criação de uma forma compreensível são a lógica e a coerência: a apresentação, o desenvolvimento e a interconexão das ideias devem estar baseados nas relações internas, e as ideias devem ser diferenciadas de acordo com sua importância e função (Schoenberg 1991, p. 27).

A partir desta declaração de caráter geral, podemos assumir que forma musical também é determinada pelo contraste que seções e elementos subsidiários fornecem, e também pelas seções principais e formações estáveis. Assim, Schoenberg afirma que "grandes formas se desenvolvem mediante o poder gerador dos contrastes" e que quanto maior a peça, maior será o número de seções contrastantes com o intuito de esclarecer a ideia principal da obra (Schoenberg 1991, p. 215). Seguindo este argumento, Schoenberg organizou nos seus manuscritos inacabados, Gedanke e Zusammenhang, Kontrapunkt, Instrumentation, Formenlehre, sumários dos "elementos da forma" nos quais ele enfatiza as pequenas seções formais baseadas principalmente em elementos 
subsidiários (Schoenberg 1995, p. 163-167; e Schoenberg 1994, p. 102-103). O sumário do manuscrito Gedanke é precedido por uma introdução onde Schoenberg lista os elementos paradigmáticos da forma, os quais incluem desde o menor elemento da forma musical, o motivo, até a pequena forma ternária. Também importante é a coerência deste sumário: é plausível assumir que a continuidade musical é alcançada através da sucessão de seções distintas, cada qual organizada de forma lógica a fim de produzir relações suficientes para validar a conexão de todas as seções como uma forma completa, um todo orgânico. Isto equivale a dizer que diferentes seções de uma forma interagem entre si, ou seja, que a nossa percepção de uma primeira seção de uma forma é modificada de acordo com a sua continuação, que necessitará de uma nova continuação e assim por diante, estabelecendo uma cadeia de seções sucessivas e inter-relacionadas entre si.

Para Schoenberg, a forma musical tem dois pré-requisitos: lógica e coerência. A partir destas duas condições, uma relação entre seções formais é criada. A coerência que Schoenberg declara como necessidade depende da firme conexão entre os pequenos elementos formais, em especial motivos e figuras motívicas. Assim, motivos, frases, gestaltes, sentenças, e períodos, todos estes elementos contribuem na definição formal de seções que são construídas de acordo com os requisitos da lógica musical. Se estas condições forem satisfeitas, a forma musical resultante torna-se compreensível.

Uma questão central na presente discussão é colocada por Dahlhaus ao comentar sobre forma sonata e forma como transformação. Dahlhaus escreve:

Não se pode negar o lugar comum que forma musical representa um processo. Mas parece que algumas das consequências deste caráter processual não foram abordadas por analistas nem na teoria nem na prática, porque música é pensada como uma cadeia linear de eventos, movendo-se adiante para uma visão completa da obra (Dahlhaus 1991, p. 113).

Mais adiante Dahlhaus comenta que considerar a percepção musical exclusivamente como um caminho que leva a um objetivo, a forma musical, é ignorar como a música funciona, e conclui afirmando que "o processo em si paradoxalmente - é o resultado" (Dahlhaus 1991, p. 114).

$\mathrm{O}$ argumento de uma forma que seja processual implica no reconhecimento de uma unidade coerente, a qual é essencialmente e 
inevitavelmente orgânica em conceito como observado por Whittall (2001). ${ }^{1}$ Essa observação nos remete ao entendimento de Schoenberg de que forma musical necessita de organização para sua plena fluência e fruição. De fato, Schoenberg está delineando um argumento que percebe a estrutura musical como sendo composta de diferentes subestruturas conectadas por certos "procedimentos formais". O conteúdo de partes, seções e segmentos são inextricavelmente conectados e a estrutura formal adquire assim um aspecto teleológico que relaciona o individual ao todo em uma forma orgânica. Schoenberg argumenta em um manuscrito de 1949 que:

Deve-se levar em conta que em música e também na poesia o reconhecimento de forma depende essencialmente de fatores distintos do que aqueles das artes. Aqui não há nenhum elemento obscuro, escondido, de maneira que o olhar não observe e a mente não avalie. $\mathrm{O}$ efeito sobre $\mathrm{o}$ intelecto é total, completo e imediato. Ele depende somente das faculdades artísticas de uma pessoa e se ela pode detectar o equilíbrio das forças centrífugas e centrípetas que constituem a forma. Simultaneamente, percebese forma e conteúdo.

Em contraste a isso, na música a aperceção da forma musical é condicionada pelo conhecimento de toda a obra. Não existe momento, em nenhum ponto da peça, nem no começo, meio ou fim, que o ouvinte esteja em posição de determinar a forma. Para termos consciência da forma devemos ter em mente não somente o conteúdo mas também aquelas forças centrífugas e centrípetas que podem finalmente parar a produção de movimento e que podem chegar a um equilíbrio.

Em outras palavras, na música, conteúdo e forma não se manifestam simultaneamente. E sem guardar na memória todos os elementos da forma e conteúdo, isto é, sem a capacidade da memória, nenhum ouvinte será capaz de perceber a forma. Em consequência disso, tudo em música deve ser formulado de maneira tal que facilite a memória (Schoenberg 1949). ${ }^{2}$

A retórica de Schoenberg é, portanto, identificável com a percepção da forma musical de acordo com o conteúdo de pequenas unidades musicais, o que permite dizer, de acordo com os pequenos elementos da forma. Assim, visando o conhecimento e esclarecimento do conteúdo musical, há uma necessidade

\footnotetext{
1 Vide verbete "Form", Grove Music Online por Arnold Whittal. Oxford Music Online: http://www.oxfordmusiconline.com:80/subscriber/article/grove/music/09981
}

$2 \mathrm{O}$ manuscrito encontra-se nos arquivos do Arnold Schoenberg Center, em Viena, manuscrito T51.17. 
MUSICA THEORICA Revista da Associação Brasileira de Teoria e Análise Musical 2020,

v. 5, n. 2, p. 165-206 - Journal of the Brazilian Society for Music

premente de uma percepção analítica, a qual, no caso específico de Schoenberg, é representada pelo que ele formula como procedimentos formais. Esta abordagem de Schoenberg é reflexo da necessidade, experimentada por teóricos e analistas do século XIX, por ferramentas descritivas do discurso musical tais como a noção de que a forma musical é iniciada por um motivo inicial e transformada em movimento através de um processo orgânico. A busca por uma unidade musical, é o cerne da questão aqui. Um exemplo é o verbete Unità no Dizionario de Peter Lichtenthal (1780-1853) de 1826:

Unidade é o mais importante dos dois grandes princípios sobre os quais a harmonia depende, não somente em música, mas em todas as artes.

Sem unidade não há som, nem acorde, cadência, frase, ou período, não há qualquer tipo de música. Com unidade e variedade, tudo caminha bem nas artes e com cada qual das suas respectivas partes. O homem de gênio deve manter estas duas coisas em equilíbrio constantemente (Lichtenthal 1826, p. 276-277).

Também importante neste sentido, são as considerações a respeito da dinâmica da forma musical. Adolphe Bernhard Marx (1795-1866) argumenta que forma musical necessita de uma dinâmica representada por ele através da noção de Repouso-Movimento-Repouso. Sendo que esta já está presente na escala diatônica onde a primeira nota e a nota final representam o repouso, mas a sucessão de notas depois da tônica representa a tensão, o movimento. Assim, Marx afirma que "a mais simples sucessão de notas musicais representa os intervalos de Repouso-Movimento-Repouso, a qual constitui a base de todas as formas musicais" (Marx 1852, p. 19). Ademais, Marx defende que o motivo deve ser considerado como um elemento primário, básico, e a partir dele constrói-se a Satz, períodos de 8 ou de 16 compassos, até a Liedform ternária ou binária. O ápice desse desenvolvimento é atingido na forma sonata, onde a seção central de desenvolvimento representa o movimento na forma, e a forma sonata é caracterizada como o ponto culminante de uma abordagem orgânica da forma musical.

O processo orgânico, como entendido por estes, e outros, comentaristas e analistas do século XIX, tem sua origem por analogia na Metamorphose der Pflanzen (1790) de Goethe. No geral, a ideia considera que inúmeras formas de vida são metamorfoses de um número limitado de arquétipos, neste caso, cada arquétipo gera um grupo de animais ou plantas. Na interpretação de Marx desta ideia, o motivo é a Urgestalt de tudo o que é musical, "assim como a vesícula 
seminal, aquele saco membranoso repleto de fluído é a configuração primária de tudo o que é orgânico - a verdadeira planta ou animal primário" (Marx 1997[1856], p. 66). A mesma ideia pode ser observada no conceito de Grundgestalt de Schoenberg, na Ursatz de Schenker, na célula básica de Réti, entre outros.

Voltando para a noção de Schoenberg onde a forma musical significa que a obra musical é "organizada", ou seja, que ela funciona tal como um organismo (Schoenberg 1991, p. 27), depreende-se que os elementos constituintes da peça devem ter, cada qual, sua função específica. De fato, Schoenberg reconhece a importância desta questão ao afirmar que "a forma de uma composição existe porque (1) um corpo existe, e porque (2) os membros exercem diferentes funções e são criados para estas funções" (Schoenberg 1975, p. 257). Esta ideia sobre função formal, já está presente em Lehrbuch der musikalischen Komposition (1850) de Johann Christian Lobe (1797-1881). Nesta obra, Lobe trata de diversas funções formais descrevendo e definindo de maneira técnica tais funções. Por exemplo, sua terminologia descreve noções como Erfindungen der Hauptgedanken (invenção do material básico), Figur (figura), Motivglied (elemento motívico) e Motivmaterial (material motívico), Modell (modelo, geralmente uma célula de um compasso geradora do período), e Sequenz (sequência, reapresentação). Além destes termos, Lobe também utiliza termos como ausspinnen (estender, derivar), fortführen (continuar), fortspinnen (estender) e Fortsetzung (expansão). Até mesmo, noções de unidade estrutural são utilizadas por Lobe, como Abschnitt (unidade de dois compassos), Periode (correspondente ao período de oito compassos e suas variações), Satz (uma unidade menor que o período que conforma-se à frase) (vide também Bent 1994, p. 198-199). Esta identificação de elementos constitutivos e geradores da forma musical aponta exatamente para a noção de uma forma musical que se constrói cronologicamente, ou seja, uma forma musical em processo de formação.

A partir destas ideias gerais sobre forma musical, Schoenberg busca comentar três maneiras diferentes de elaboração motívico-temática destinadas a três tipos de linguagem musical de épocas diferentes, desdobramento motívico (unfolding), variação progressiva (developing variation) e prosa musical (musical prose). Cada uma destas maneiras de se referir ao tratamento motívico em obras musicais, torna-se característico de observações analíticas pertinentes a diferentes épocas musicais na visão de Schoenberg. Assim, a desdobramento 
motívico, Schoenberg se refere ao comentar a música de J. S. Bach; variação progressiva é característica do estilo homofônico-melódico (classicismo e romantismo); e prosa musical típico do tratamento dado por Brahms, Wagner, Mahler em aspectos motívicos e em sua própria obra, diz Schoenberg. Apesar das delimitações cronológicas sugeridas por Schoenberg, nem todas as categorias estão restritas a apenas um estilo musical. Variação progressiva também ocorre na música de J. S. Bach, mas também na de Beethoven e Brahms, assim como prosa musical ocorre na música de Brahms, mas também ocorre em recitativos de óperas de Mozart e de cantatas de Bach. Portanto, a escolha de exemplos musicais neste texto que não façam parte do repertório abordado por Schoenberg em seus escritos e análises, é justificada para validar ideias e suas aplicações em análise musical. Para ilustrar estas técnicas de tratamento motívico utilizarei exemplos pertencentes, mas também outros que não, ao cânone schoenberguiano.

\section{Desdobramento motívico}

Uma característica frequentemente observada na música de J. S. Bach diz respeito a uma técnica utilizada onde os mesmos elementos motívicos constituintes de um tema são reorganizados e reordenados. Uma ilustração simples deste tipo de procedimento técnico/composicional pode ser observada no Prelúdio e Fuga n. 5 do primeiro livro do Cravo Bem Temperado. O Exemplo 1a ilustra os dois primeiros compassos da obra. Aqui se observa que a repetição motívica (motivo $a$ ) ocorre de maneira quase sempre variada e reordenada. Por exemplo, entre o motivo inicial $a$ e $a 1$ ocorre uma variação por reordenamento de notas e que produz uma inversão do sentido ascendente inicial do motivo. Já o motivo $a 2$ retorna a um nível de reconhecimento mais próximo ao motivo inicial $a$, mas ao mesmo tempo gera variação e produz os motivos subsequentes $a 3$ e $a 4$. Somente o motivo $b$ parece ser distinto pela sua terminação, mas sua relação com o motivo inicial também é clara. No Ex. 1b (c. 21-22) o motivo $a$ dá origem a novas figuras motívicas proximamente relacionadas com sua origem, a5 é uma transposição de $a$, e a figura motívica identificada como $c$ é composta internamente pelos motivos $b$ e $a$. Também é identificada como $c$ por se assemelhar a figura inicial do sujeito da fuga (Ex. 1c) que é derivado dos motivos apresentados no prelúdio. Assim, a elaboração motívica atinge uma 
permeabilidade por toda a obra (prelúdio e fuga) e produz a sensação de unidade sonora.

a)

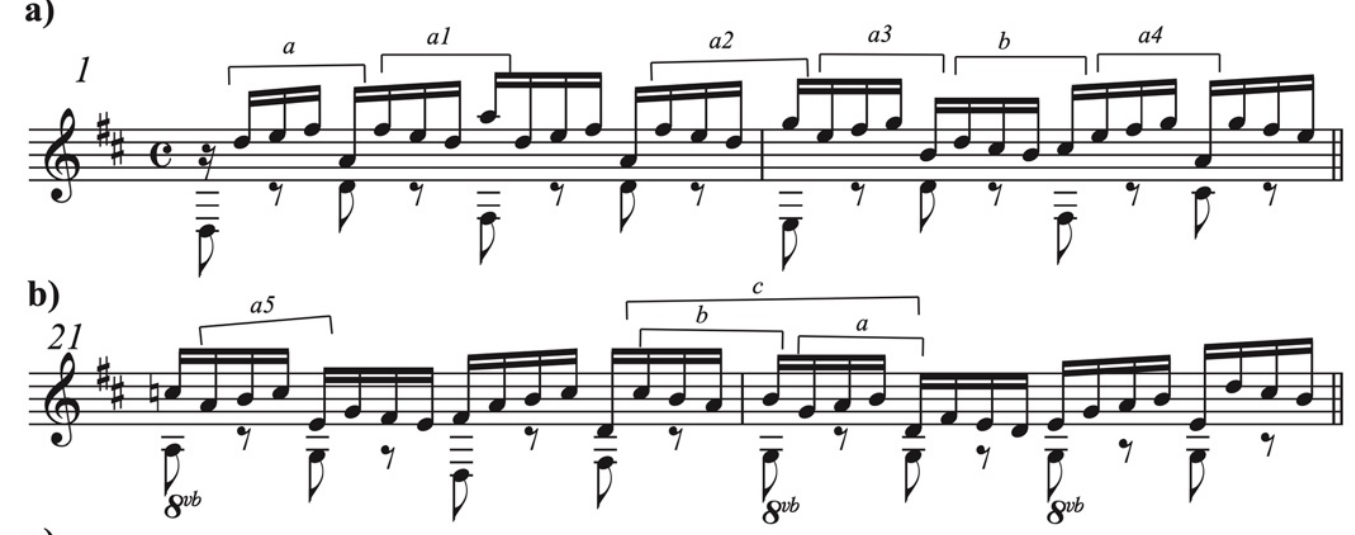

c)

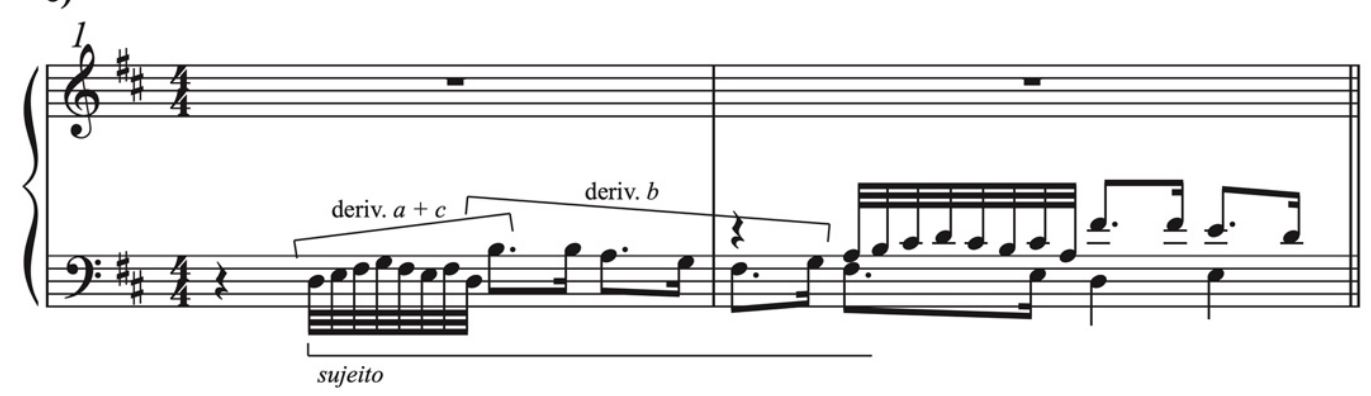

Exemplo 1a-c: J. S. Bach, Excerto de Prelúdio e Fuga em Ré maior, n. 5, BWV 850.

Outro exemplo de desdobramento motívico pode ser observado na Fuga n. 6 em Ré menor do Cravo Bem Temperado. O sujeito da fuga compreende três motivos identificados como $a, b$ e $c$. O Ex. 2a mostra, nos c. 1-2 da peça, o início da primeira exposição do sujeito na tônica. Nos c. 3-4 a primeira resposta é realizada e os motivos se repetem. Aliás este é um ponto importante para Schoenberg, em fugas naturalmente ocorre a repetição constante de temas e todo o material motívico é organizado de acordo com este(s) tema(s). Assim, no Ex. $2 \mathrm{~b}$, é apresentado um desdobramento do motivo $b$ (c. 9-10) que acaba predominando no primeiro episódio da fuga. Mas o desdobramento motívico nesta peça é orgânico, ou seja, permeia todas as seções, seja exposição, episódios e stretti. Este é o caso ilustrado no Ex. 2c onde o stretto ocorre com a inversão do sujeito. No c. 21 o sujeito é apresentado na sua forma original. Continua no compasso seguinte a apresentação do sujeito invertido. O material motívico, apesar da inversão do sujeito, é reconhecível pelas constantes reapresentações, i.e. é um material memorável e que facilita a compreensão da coerência, lógica e 
unidade da fuga. O efeito resultante é de uma peça coesa e fluente, com variações "mas que tem uma combinação básica que é a origem de todas as outras combinações" (Schoenberg 1975, p. 397).
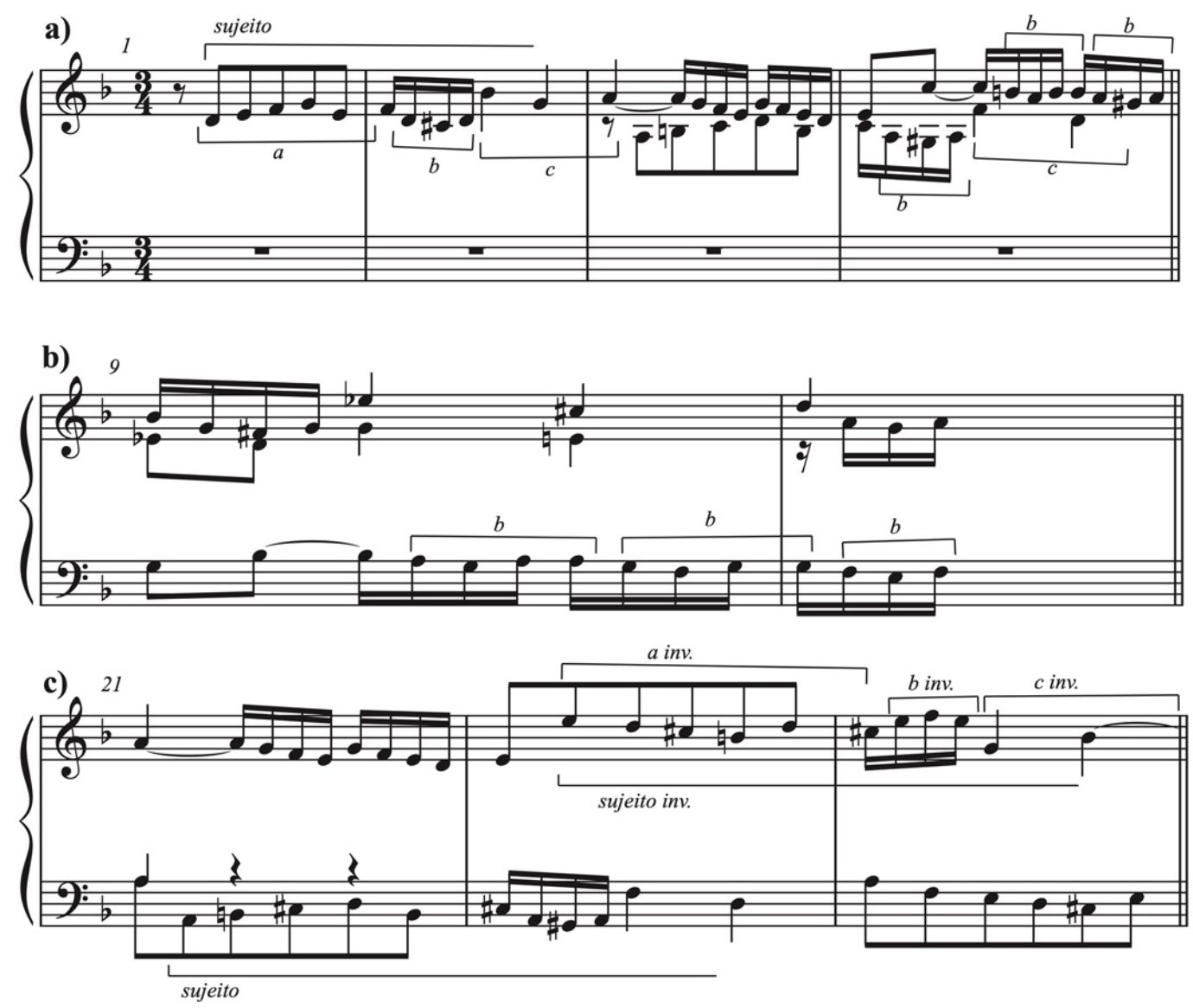

Exemplo 2a-c: J. S. Bach, excertos da Fuga em Ré menor, n. 6, BWV 851.

Estas observações a respeito da escrita motívica de Bach, tomam forma teórica nas observações de Schoenberg sobre música contrapontística. Para ele a música de J. S. Bach é caracterizada por um processo motívico de "desdobramento" do material motívico básico. Este tipo de técnica composicional, característica, segundo Schoenberg, de um estilo composicional contrapontístico é consumada pelo procedimento no qual "uma configuração ou combinação básica tomada à parte e reagrupada em ordem diversa contém tudo que poderá gerar uma nova sonoridade posteriormente àquela já apresentada na configuração original" (Schoenberg 1975, p. 397). Apesar de Schoenberg estar se referindo especificamente ao processo motívico em fugas de J. S. Bach, ele também aborda desdobramento como um método para composições nas quais 
... este estilo é baseado no fato de que um número de notas está em uma relação mútua de sucessão e simultaneidade (contrapostas), de maneira que todas as configurações que aparecem no decorrer da obra já estão contidas, formadas ou apresentadas nesta Grundgestalt, ou são parcialmente determinadas por esta possibilidade. A obra resultante simplesmente se "desenrola" como um filme, quadro por quadro, gestalt por gestalt, e até mesmo a sequência de eventos aqui é lógica e quase que completamente já determinada (Schoenberg 1995, p. 400).

A distinção que Schoenberg faz entre a música homofônica e contrapontística ilustra sua percepção de diferentes técnicas de composição musical, para a primeira variação progressiva, a qual comentarei em seguida, e para a segunda desdobramento. Muito embora a referência principal de desdobramento motívico seja as fugas de J. S. Bach, Schoenberg também possibilita (ou admite) o uso desta técnica em música não contrapontística, mas que seja composta com a ideia inicial apresentada como um Grundgestalt e que seja desenvolvida por desdobramento. Um caso modelar na aplicação desta técnica é o Prelúdio da Suite Antiga op. 11 de Nepomuceno. O Ex. 3a ilustra os c. 1-5 da peça. A figura motívica inicial marcada como a (c. 1) é a ideia básica a partir da qual as subsequentes se desdobram. Assim, a figura a1 é um desdobramento inicial de a e é caracterizado pela maioria de graus conjuntos e a2 é uma transposição à quinta justa inferior. No Ex. 3b, c. 28, a figura motívica a3 é apresentada e constitui-se somente de graus conjuntos. No entanto, ainda é possível reconhecer seu desdobramento a partir de a. No c. 29 ocorre novo desdobramento e a figura a4 é constituída por graus conjuntos ascendentes e descendentes tal qual a figura a3. No c. 30 há a reapresentação da figura a com ligeira modificação na sua terminação. E no c. 31 a figura a5 é uma transposição de a uma quinta justa inferior. A Suite Antiga de Nepomuceno é uma estilização da música do período barroco no contexto da música romântica brasileira. A utilização desta técnica motívica denota a atenção do compositor brasileiro sobre minúcias da linguagem musical de outras épocas.

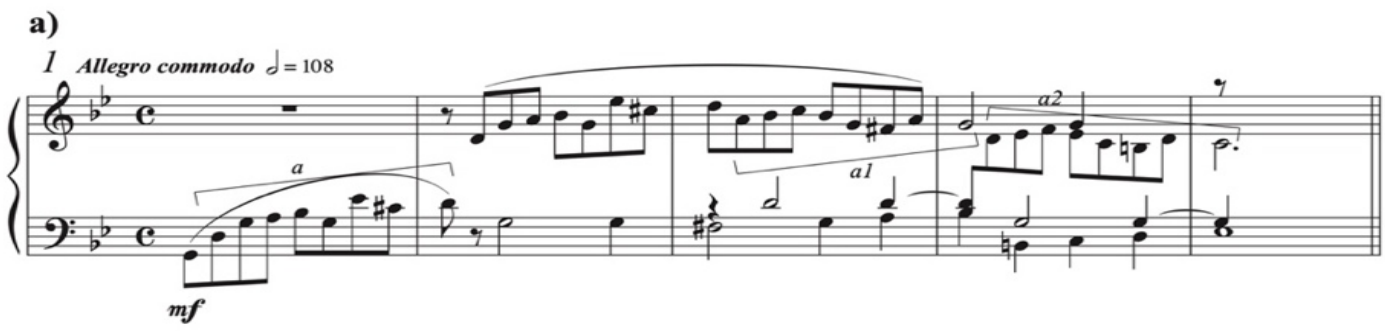



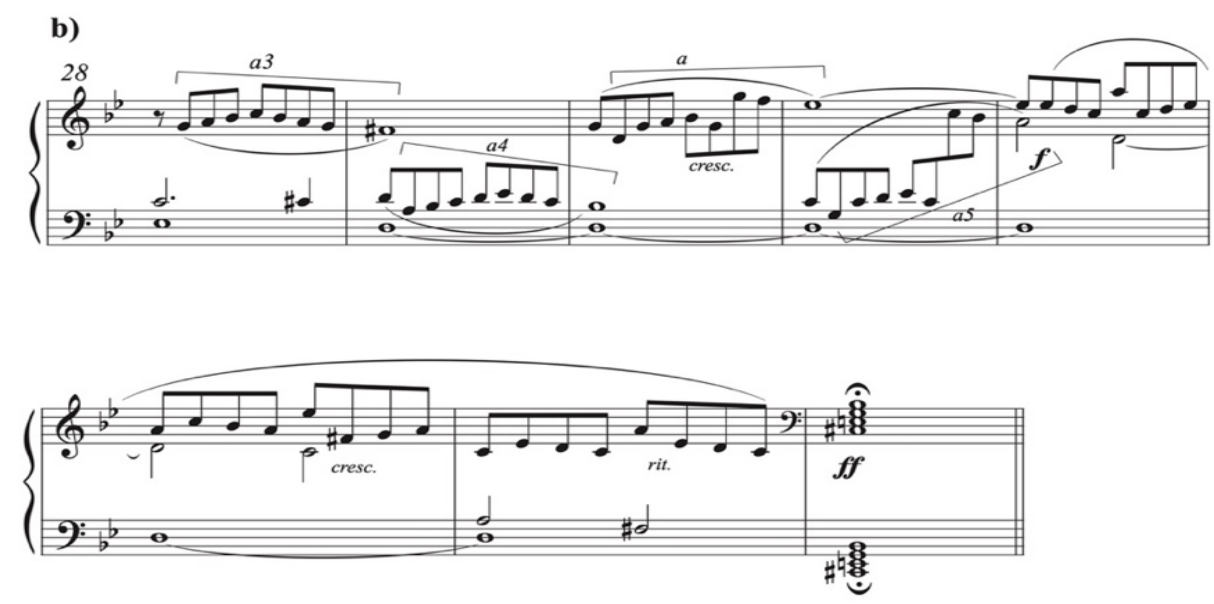

Exemplo 3a-b: Nepomuceno, excertos de Prelúdio, Suite Antiga, Op. 11.

Heitor Villa-Lobos, nas suas Bachianas Brasileiras, inspirado pela linguagem musical de J. S. Bach também utiliza desdobramento motívico no primeiro movimento da sua Bachianas Brasileiras n. 6. O tema inicial da peça, apresentado pelo fagote a partir do c. 3, é composto por um motivo inicial $a$ de um arpejo da tônica, Ré menor, intercalado por um grau conjunto. Este é seguido por uma inversão modificada em forma de arpejo a qual é seguida por nova modificação do motivo $a$ (no Ex. 4a são indicadas pelos colchetes). A terminação do tema apresenta o motivo $b$. Nos c. 5-7 o motivo $a$ é fragmentado e seguido do motivo $b$. Finalmente no c. 7 a flauta apresenta o motivo $a$ com a diminuição rítmica do arpejo ascendente. Este intenso trabalho de desdobramento motívico também é aplicado na passagem (Ex. 4b) em que o fagote apresenta o motivo $a$ expandido no c. 13 e subsequentemente fragmentado. Já a flauta apresenta, nos c. 15-16, o motivo a e sua inversão modificada. $\mathrm{O}$ desdobramento motívico utilizado por Villa-Lobos é uma referência importante de uma técnica motívica observada por Schoenberg a respeito da música de Bach. Importante salientar que o simples desdobramento motívico não gera novas ideias musicais, mas sim a continuidade da ideia prima que é elaborada continuamente. 
a)
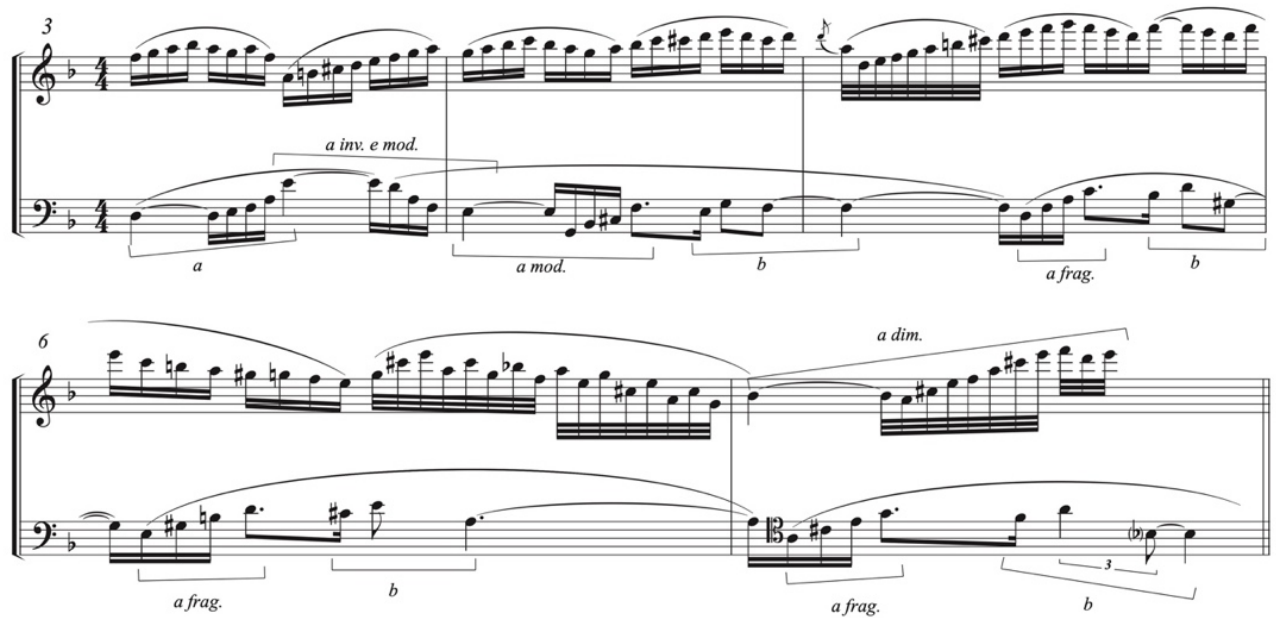

b)

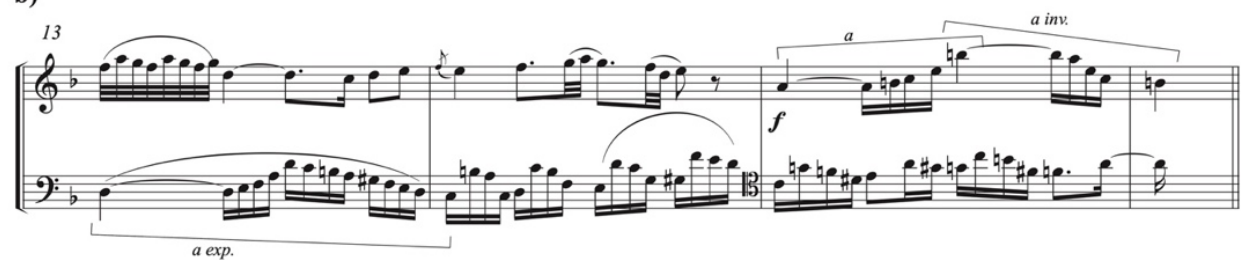

Exemplo 4a-b: Villa-Lobos, excertos de Bachianas Brasileiras, n. 6/i.

\section{Variação progressiva}

Ao formular seu princípio de variação progressiva Schoenberg também propõe sua própria versão da fórmula "unidade na diversidade". Esta noção propicia a criação de variedade em estruturas localizadas e em larga-escala através da integração do material básico, representado pela Grundgestalt, e desenvolvido por variação progressiva, à estrutura formal da obra (Dahlhaus 1991, p. 51-52). Ademais, e em um sentido mais amplo, variação progressiva pode ocorrer em outros parâmetros além do aspecto motívico-temático de uma obra, ou seja, pode influenciar o desenvolvimento harmônico e rítmico.

O termo "variação progressiva" denota aspectos diferentes de uma técnica de composição. Ele implica uma noção de "crescimento" relacionado à abordagem orgânica de variação motívica, distinta daquela associada à técnica de variação propriamente dita, como em um tema com variações, por exemplo. Neste sentido, a conexão entre diferentes motivos pode ser entendida como não tendo uma relação direta, ou seja, variações progressivas de um mesmo motivo podem ter seu conteúdo essencial derivado de uma característica comum, muito embora esta não seja uma condição sine qua non. Portanto, em variações 
progressivas de um motivo básico, podem não existir uma relação facilmente identificável entre as variações mais longínquas. Por exemplo, em uma série de quatro motivos desenvolvidos a partir de um básico, o segundo pode ter uma relação direta com o primeiro, mas as terceira e quarta variações podem ou não apresentar características que sejam relacionadas ao motivo inicial. No entanto, entre o terceiro e quarto motivo haverá uma conexão mais forte do que entre o terceiro ou quarto e primeiro ou segundo motivos. Schoenberg aborda esta evolução motívica considerando o uso de gestaltes intermediárias entre ideias contrastantes, e a noção de Grundgestalt como o elemento unificador mais importante. Esta observação abre a possibilidade de entendimento de variação progressiva como um processo gradual de desenvolvimento motívico que toma forma de maneira cronológica. Em outras palavras, existe um processo gradual de desenvolvimento motívico que ocorre e se conforma a estágios intermediários em direção de novas figuras e ideias motívicas, gerando assim uma nova ideia musical. Schoenberg reconhece que a natureza de desenvolvimento contínuo em variação progressiva pressupõe que a referência à Grundgestalt pode ser alcançada somente em relação a estágios intermediários de desenvolvimento. A esse respeito, ele escreve que:

Mesmo que tenhamos mudanças muito grandes, estas são associadas com uma gestalt que media entre as variações mais remotas e a gestalt inicial por se assemelhar a ambas, enquanto traz simultaneamente à memória a gestalt inicial.

Um grau significativo de distanciamento da gestalt inicial é encontrado naquelas variações que introduzem ideias subordinadas. Frequentemente sua conexão à grundgestalt (quase sempre indireta) tornase clara muito tarde [na obra]. Como regra estas gestaltes dificilmente se desenvolvem de maneira convencional, mas sim de trás para frente: elas se aproximam da gestalt inicial (Schoenberg 1995, p. 159).

Ilustrativo destas gestaltes intermediárias que dão origem a temas subordinados, como o tema secundário de uma forma sonata, é mostrado no Ex. 5a-c (baseado em Schoenberg 1975, p. 164). O Ex. 5a mostra o tema inicial da Sinfonia n. 5 de Beethoven que é derivado para a gestalt intermediária (Ex. 5b) que por fim origina o tema secundário da forma sonata da obra (Ex. 5c). Assim, a passagem intermediária corresponde a uma variação progressiva que conduz a uma ideia nova, o tema secundário. 

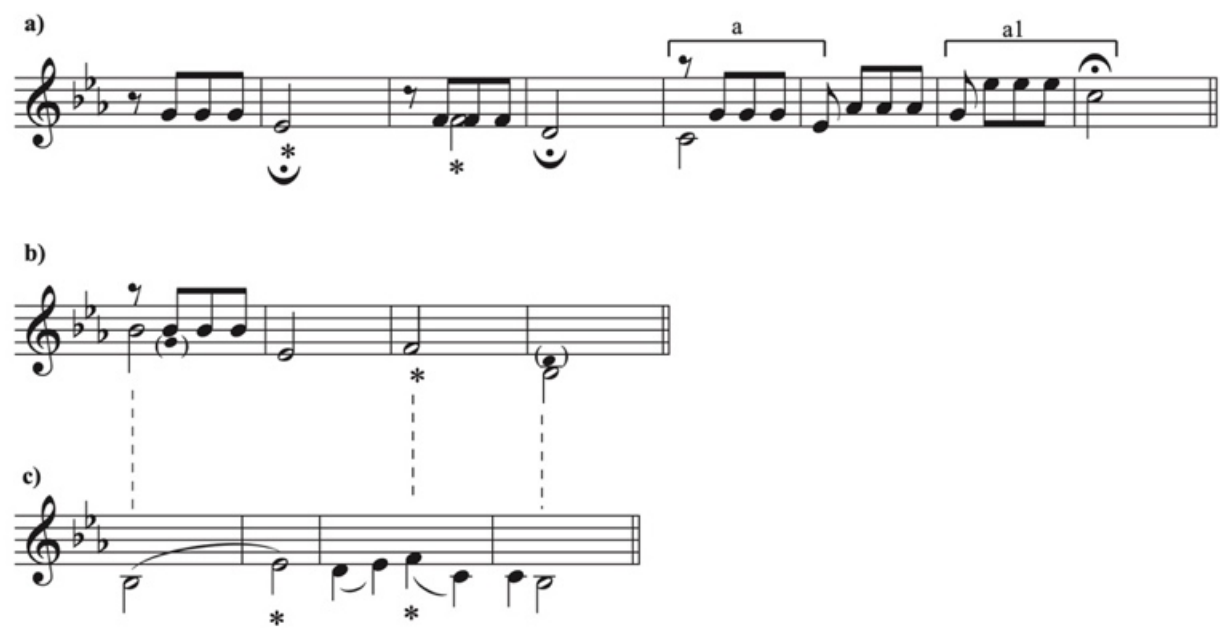

Exemplo 5a-c: baseado em Schoenberg, Style and Idea, Exemplo 1-3, p. 164; excertos de Beethoven, Sinfonia n. 5, primeiro movimento.

Estas conexões dependem do desenvolvimento cronológico de um material básico e da aceitação de um processo teleológico. Sua importância e validade são alcançadas somente se vistos em relação a uma abordagem e entendimento orgânicos do processo de composição musical, isto é, somente em relação a uma Grundgestalt a partir da qual todo o restante é derivado. É deste ponto de vista que Simms argumenta que variação progressiva tem dois objetivos: ela ajuda a criar "uma melodia sofisticada e artística por um desenvolvimento rápido dos elementos motívicos iniciais", e ela relaciona "melodias aparentemente diferentes tendo como base formas-motívicas que evoluem de maneira contínua" (Simms 2000, p. 34; ver também Haimo 1997, p. 355-356). É apropriado acrescentar que a evolução de formas motívicas gera ideias musicais distintas, ou seja, um novo tema musical.

Portanto, central à discussão que Schoenberg nos oferece é a inter-relação entre os conceitos de Grundgestalt e de variação progressiva. Estes dois conceitos têm a função de prover unidade para a obra musical e através da lógica e coerência, em particular, a motívica, a compreensibilidade da obra é alcançada. Esta é a ideia que Dahlhaus defende, ou seja, que variação progressiva é um processo de desenvolvimento de uma ideia básica (Dahlhaus 1987, p. 128).

A análise de Schoenberg do primeiro movimento do quarteto em Dó maior, K. 465, ilustra o conceito de variação progressiva como um processo motívico gradual. Esta análise está em dois escritos de Schoenberg, 
MUSICA THEORICA Revista da Associação Brasileira de Teoria e Análise Musical 2020,

v. 5, n. 2, p. 165-206 - Journal of the Brazilian Society for Music

Zusammenhang, Kontrapunkt, Instrumentation, Formenlehre (1917) e no manuscrito Gedanke (1934-36). ${ }^{3}$ Schoenberg observa sobre esta obra de Mozart que se trata de "um dos exemplos mais perfeitos de variação progressiva" (Schoenberg 1994, p. 43).

Schoenberg inicia sua análise identificando o conteúdo motívico da Grundgestalt do quarteto. O Ex. 6 ilustra o material básico que inclui: motivo $a$, o qual é formado pela figura de três colcheias (Dó ${ }^{4}-\mathrm{Re}^{4}-\mathrm{Mi}^{4}-\mathrm{Sol}^{4}$ ); motivo a1, que define uma quinta justa ascendente $\left(\mathrm{Dó}^{4}-\mathrm{Sol}^{4}\right)$; $a 2$, que define a segunda maior

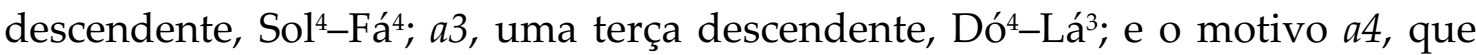
delineia uma quarta justa ascendente entre as notas inicial, Dó ${ }^{4}$ e a final, Fá4. O motivo rítmico $Z$ é enfatizado no decurso da peça. Além deste conteúdo motívico, podemos identificar uma estrutura maior, a figura $A$ que compreende o movimento melódico Dó ${ }^{4}-\mathrm{Dó}^{4}-\mathrm{Re}^{4}-\mathrm{Mi}^{4}-\mathrm{Sol}^{4}-\mathrm{Fá}^{4}$.

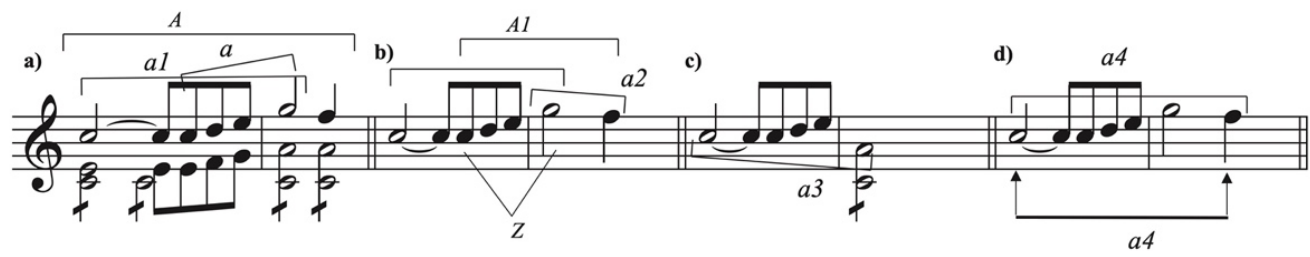

Exemplo 6: Grundgestalt de Mozart, quarteto para cordas, K. 465, primeiro movimento.

A primeira sentença (c. 23-30) consiste em um segmento inicial (c. 23-26) que repete a Grundgestalt nas formas de tônica e dominante. Na segunda metade da sentença inicia-se um processo de liquidação através da repetição do compasso inicial na tônica. ${ }^{4} \mathrm{~A}$ transposição, uma quinta justa acima do motivo $a$ $\left(S_{0}{ }^{4}-\mathrm{La}^{4}-\mathrm{Si}^{4}-\mathrm{Dó}^{5}\right)$, não somente inicia o processo de liquidação, mas também gera um novo motivo $b$ (Dó $\left.{ }^{5}-\mathrm{Mi}^{4}-\mathrm{Fá}^{4}\right)$. Finalmente, o processo de liquidação é concluído por figuras de fragmento escalar derivadas do motivo $a$ e uma simples repetição do motivo $b$ transposto. Além disso, a sentença projeta uma progressão em Dó: I-V, o que permite que a estrutura possa ter uma continuação imediata,

\footnotetext{
${ }^{3}$ Publicados e traduzidos para o inglês como Coherence, Counterpoint, Instrumentation, Instruction in Form (1994) e The Musical Idea and the Logic, Technique, and Art of its Presentation (1995).

${ }^{4}$ Schoenberg define liquidação como "um processo que consiste em eliminar gradualmente os elementos característicos, até que permaneçam, apenas, aqueles não-característicos que, por sua vez, não exigem mais uma continuação" (Schoenberg 1967, p. 58).
} 
uma vez que motívica e tonalmente permanece como uma estrutura aberta (vide Ex. 7).

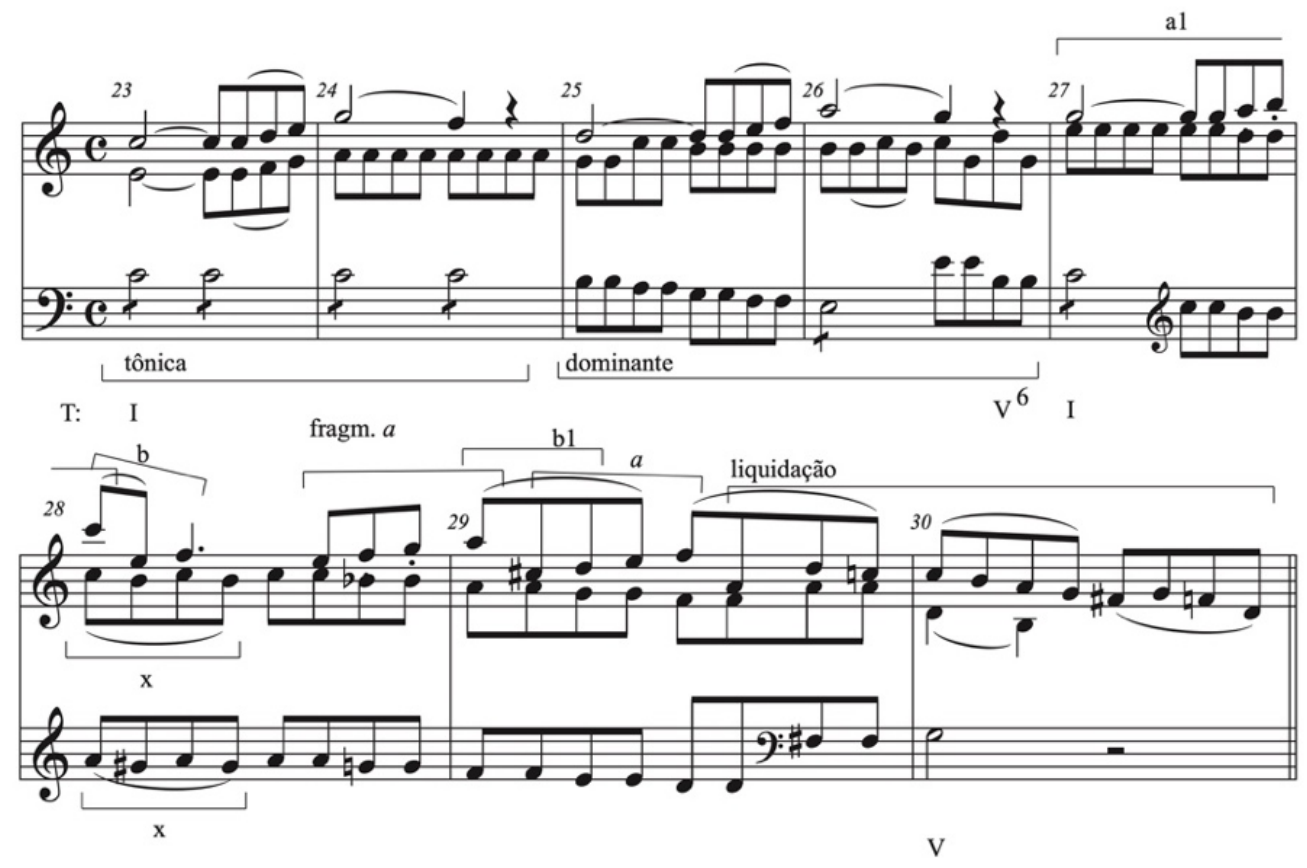

Exemplo 7: excerto de Mozart, quarteto para cordas, K. 465, primeiro movimento.

As observações de Schoenberg sugerem que há um processo de derivação motívica contínua, no qual os motivos $a$ e $b$ geram uma nova ideia musical, neste caso o tema secundário da forma sonata. O Ex. 8 ilustra o desenvolvimento de variações a partir do motivo básico $(a)$ até o tema secundário. Torna-se, então, claro que há um trabalho de desenvolvimento motívico gradual e progressivo. Por exemplo, o motivo $b$ é claramente derivado de $a$, e a aceleração rítmica aplicada ao motivo $b$ resulta em um desenvolvimento gradual. No Ex. 8b é ilustrado o conteúdo motívico do tema subordinado. Este inicia com uma terça ascendente seguida de uma segunda descendente, ou seja, a mesma relação intervalar do motivo $b$ (sexta descendente [ou terça ascendente] e grau conjunto). A gestalt de terças alternadas que segue é composta por apresentações sucessivas do motivo $b^{\prime}$. Além disso, a gestalt completa do tema subordinado também delineia o intervalo de quinta justa descendente, ou seja, uma inversão do motivo $a 4$ (vide Ex. 6d). 
a)
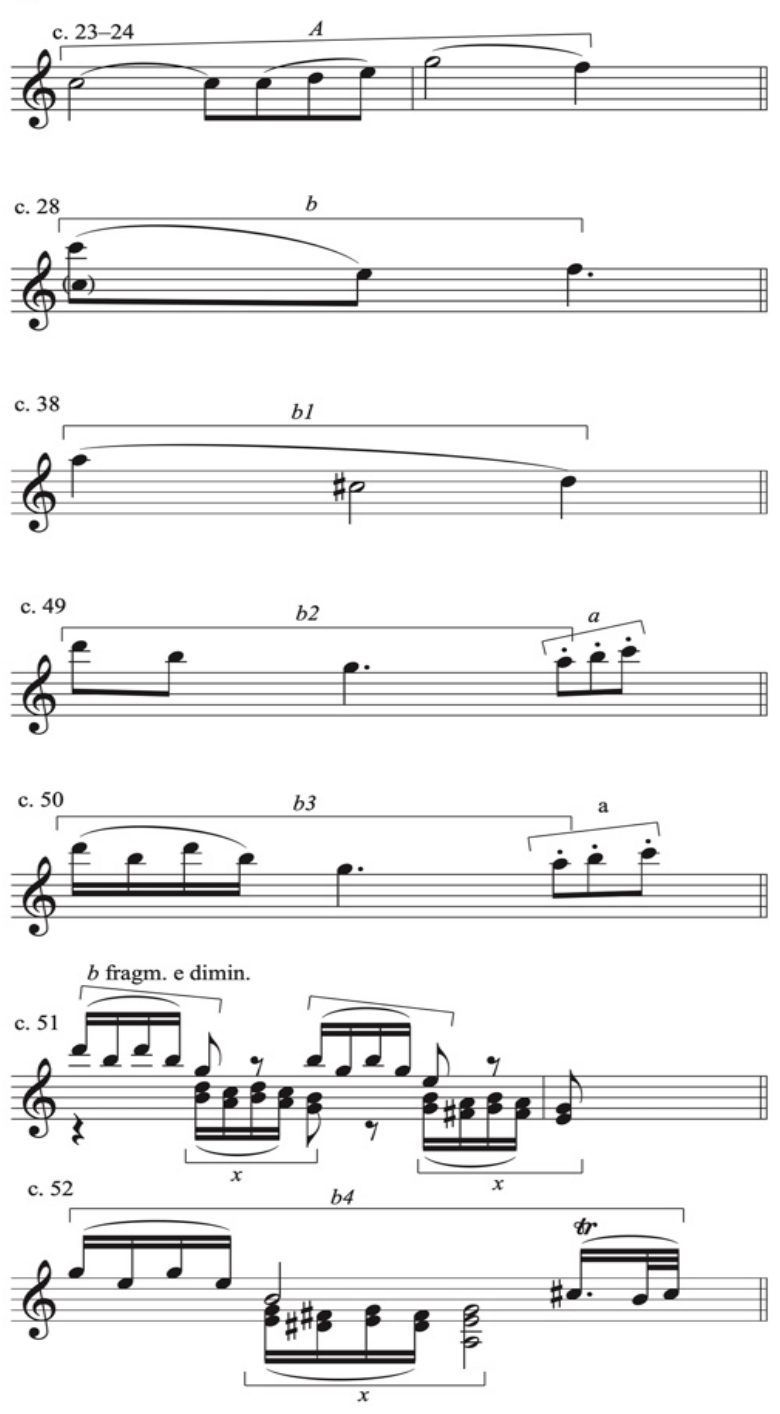

b)

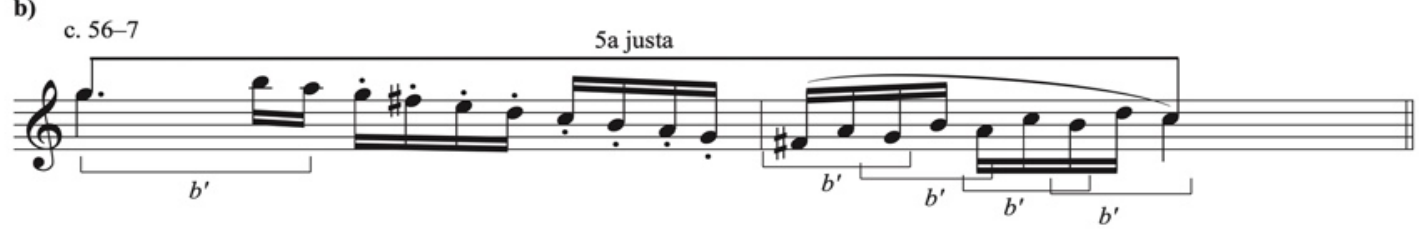

Exemplo 8: derivação motívica em Mozart, quarteto para cordas, K. 465, primeiro movimento.

A importância da Grundgestalt como referência motívica é evidenciada na seção de desenvolvimento da forma sonata e de como o compositor faz variações constantes do motivo inicial $a$ (vide Ex. 9). No Ex. 9a, c. 107-108, o motivo ainda se assemelha bastante ao inicial, mesmo com a expansão do intervalo entre a nota mais grave $\left(\mathrm{Dó}^{4}\right)$ e a mais aguda $\left(\mathrm{La}^{4}\right)$. Esta ampliação do intervalo da nota mais 
grave para a mais aguda é fator importante para a variação motívica que ocorre. No Ex. 9c, c. 112-113, a viola toca a nota mais grave, Dó\#³, e a mais aguda, Dół ${ }^{4}$, compreende um intervalo de oitava diminuta e delineia uma sequência de terças e grau conjunto; já no Ex. 9h o violoncelo tem como nota mais grave $\mathrm{Mi}^{1}$ e mais aguda Fá ${ }^{2}$ uma nona menor; delineia o arpejo de um acorde de sétima de dominante. Outras variações também ocorrem, por exemplo, no Ex. 9j há a supressão da nota inicial do motivo inicial restando as 3 colcheias que fazem parte do arpejo, e no Ex. 9m o motivo inicial é transformado em um arpejo de sétima de dominante para o retorno para a tônica (Dó maior).
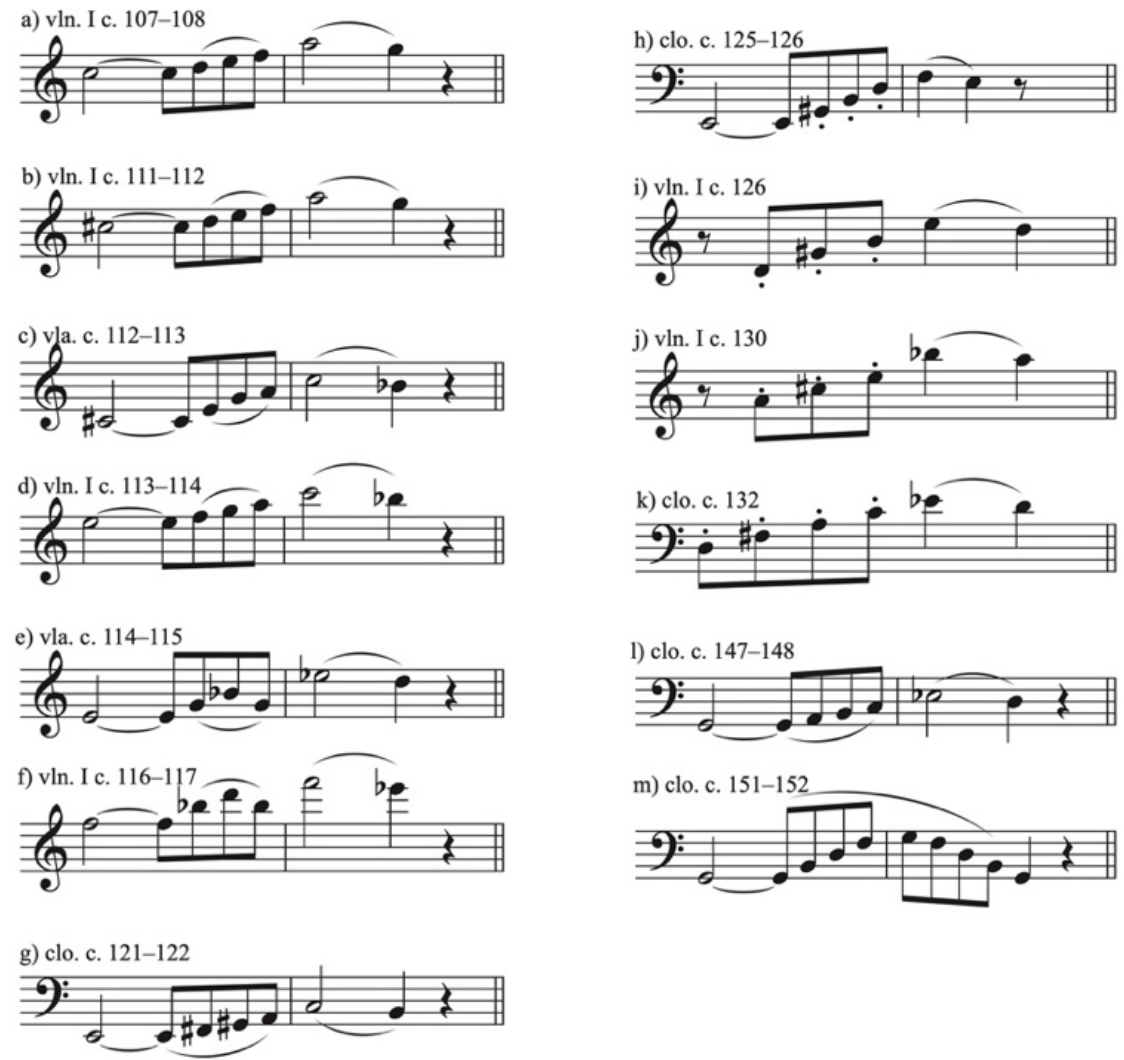

Exemplo 9a-m: derivação motívica em Mozart, quarteto para cordas, K. 465, primeiro movimento.

Outro exemplo de variação progressiva ocorre nas Variações Diabelli Op. 120 de Beethoven. A abordagem teórica de Schoenberg para a forma tema com variações considera a técnica de variação como a ferramenta composicional aplicada para produzir contraste e variedade e, portanto, assume um papel de "princípio estrutural" para toda a obra. O conjunto organizado de variações, é 
composto primariamente de repetições que "seriam intoleráveis" sem o estímulo constante causado pelo material variado. Schoenberg observa que as relações entre o tema e suas variações são estritas e resultam da concordância entre as proporções estabelecidas no tema e duplicadas em cada variação. Assim, estas proporções não devem ser alteradas, mesmo que o caráter o seja. Portanto, "são preservadas as proporções, as relações estruturais das partes e os principais elementos...Cada variação deve possuir a mesma qualidade de auto-suficiência formal e coerência que possui o tema" (Schoenberg 1991, p. 203). Neste sentido, a forma tema com variações, para Schoenberg, é de caráter absolutamente estrito. O tema, por sua vez, apresenta a ideia básica a partir da qual todas as variações devem ser estruturadas, ou seja, o tema representa a forma básica, a Grundgestalt da obra. Nelson explica quais elementos são importantes no tema e consequentemente nas variações. Ele identifica três aspectos principais na forma: 1. a estrutura melódica; 2. uma estrutura básica harmônico-estrutural; 3 . elementos definidores de caráter. Nelson entende que a unidade é assegurada ao estabelecer "um equilíbrio entre as mudanças na estrutura melódica e aquelas na estrutura básica harmônico-estrutural". Isto é realizado ao aplicar os métodos de elaboração motívica, técnica composicional emprestada de outras formas e que apresentam o equilíbrio formal e tonal como seus objetivos principais (Nelson 1948, p. 126-127). Portanto, a relação de unidade e coerência da forma é estabelecida e afasta o perigo de monotonia.

$\mathrm{O}$ desenvolvimento cronológico do tema pode resultar no "desenvolvimento de uma ideia que na primeira apresentação pode parecer insuficiente para impulsionar a obra, mas que através do tratamento (de variação) aumente em interesse, ou seja, seu propósito principal é revelado somente de maneira gradual" (Cone 1989, p. 16). É nesta perspectiva que Dahlhaus considera a forma como discursiva, ou seja, um fluxo constante de ideias que enfatizam a estrutura melódica da obra, e não os fatores rítmico e dinâmico, mas sim a obra completa é ouvida como uma rede de relações melódicas (Dahlhaus 1975, p. 20-21). Portanto, o argumento principal é de derivações temático-motívicas de acordo com um processo gradual de desenvolvimento estrutural-formal da obra, e que cada uma das variações apresente suas próprias características gerando variações progressivas que conduzem a novas ideias musicais. 
Assim, os seguintes comentários analíticos sobre aspectos das Variações Diabelli se concentram no entendimento de desenvolvimento motívico, mas também almejam demonstrar a unidade e coerência da obra, dentro do contexto de forma como processo gradual e de variações progressivas do tema. ${ }^{5}$

Tovey, no seu ensaio sobre as Variações Diabelli, indicou quatro motivos: 1. O grupeto inicial; 2. Os intervalos de quarta descendente e de quinta na primeira frase; 3. A linha do baixo no primeiro segmento; e 4 . O uso de modelo e sequência (Tovey 1944, p. 124-134). Podemos reinterpretar a identificação motívica de Tovey com os motivos apresentados no Ex. 9: motivo $a$, consiste na apojatura de Ré, passando por Dó, Si e retornando a Dó; motivo $b$, o intervalo de quarta justa descendente entre Dó e Sol e a quarta justa ascendente no baixo (b1); motivo $c$, os acordes e notas repetidas. Estes motivos caracterizam os motivos mais proeminentes do tema (Ex. 10).

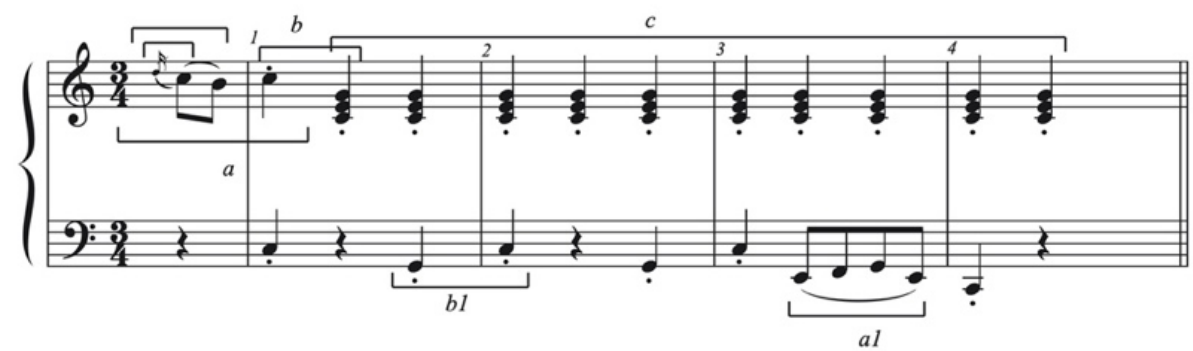

Exemplo 10: Beethoven, Variações Diabelli, Op. 120, conteúdo motívico do tema.

O desenvolvimento motívico durante as variações é extraordinário. $\mathrm{O}$ compositor elabora uma correspondência motívica entre variações que sejam baseadas no motivo $a$ e outras baseadas nos motivos $b$ e $c$. Nos Exs. 11a-c, encontra-se na coluna $a$ algumas das derivações do primeiro motivo e na coluna $b$ as derivações dos motivos $b$ e $c$. A partir desta tabela pode-se identificar que a elaboração motívica na obra é essencial e gera as características de cada uma das variações como uma nova ideia musical derivada da Grundgestalt (o tema). ${ }^{6}$ Não é o caso aqui comentar cada uma das variações de forma extensiva. Porém, comentários sobre algumas das variações parecem ser suficientes para que

\footnotetext{
${ }^{5}$ É importante notar que a intenção aqui não é realizar uma análise desta obra de Beethoven, mas sim exemplificar aspectos motívicos pertinentes ao assunto "variação progressiva".

${ }^{6}$ Exceções ocorrem com as variações que são relacionadas como pares ou grupos, por exemplo variações 26 e 27.
} 
percebamos como a variação progressiva aplicada aos motivos identificados geram novas ideias musicais. Por exemplo, na coluna $a$, as variações 3 e 9 são caracterizadas pela utilização de motivo da variação. Schoenberg esclarece que motivo da variação, "deve consistir de uma figura predeterminada, modificada apenas de acordo com as acomodações que a estrutura e a harmonia requeiram" (Schoenberg 1991, p. 203); assim, na variação 3 o motivo $a$ é modificado para uma sequência de notas por saltos seguida de grau conjunto, um motivo que determina toda a variação. O mesmo ocorre na variação 9, porém o motivo $a$ é mantido na sua forma original e determina as características da peça. Outros casos mostram como Beethoven modifica o motivo $a$ : nas variações 6, 16 e 21 o motivo é modificado para um trinado; na variação 11 é transformado em uma tercina, na variação 13 em simples notas repetidas, na variação 14 é modificado para um motivo de colcheia duplamente pontuada seguida de fusas. Na coluna $b$ estão algumas das derivações dos motivos $b$ e $c$. Notável é já a derivação na variação 1, onde o motivo $b$ é modificado para uma simples anacruse com notas repetidas, já o motivo $c$ de acordes repetidos é modificado para o ritmo da marcha que caracteriza esta variação. Algumas das variações se aproximam mais do modelo do tema. Por exemplo, variação 15 o motivo $b$ e $c$ são bastante semelhantes ao motivo original. $O$ mesmo acontece com a variação 17 , porém os motivos são apresentados na parte grave do piano. No entanto, casos de derivação motívica distantes também são explorados pelo compositor. Este é o caso da variação 20, um cânone misterioso por conta de seu andamento, lento e sério, e de seu acentuado contraste em relação à dançante valsa do tema. $\mathrm{Na}$ variação 22 a derivação motívica é percebida pelo compositor como citando o início da Introduzione da primeira cena, notte e giorno faticar, ato I, de Don Giovanni k. 527 de Mozart. Por fim há as derivações mais complexas exemplificadas no Ex. 11c. Nas variações 24 e 30 o motivo $b$ dá origem a um processo de imitação como em um fugato que atinge seu clímax na variação 32, uma fuga dupla. Ainda na variação 31 o motivo $a$ é ornamentado como uma septina, seguido de elaboração dos motivos principais do tema. Assim, a exploração das possibilidades de variação progressiva nos motivos do tema é levada às suas últimas consequências por Beethoven, a tal ponto que cada uma das variações apresenta ideias musicais novas derivadas daquelas iniciais representadas pelo tema. 
Tabela geral de correspondências motivicas

a) derivações do motivo $a$

Tema

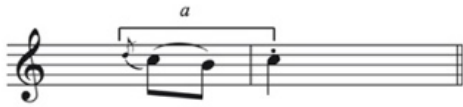

Var. 2

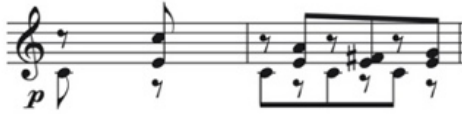

Var.
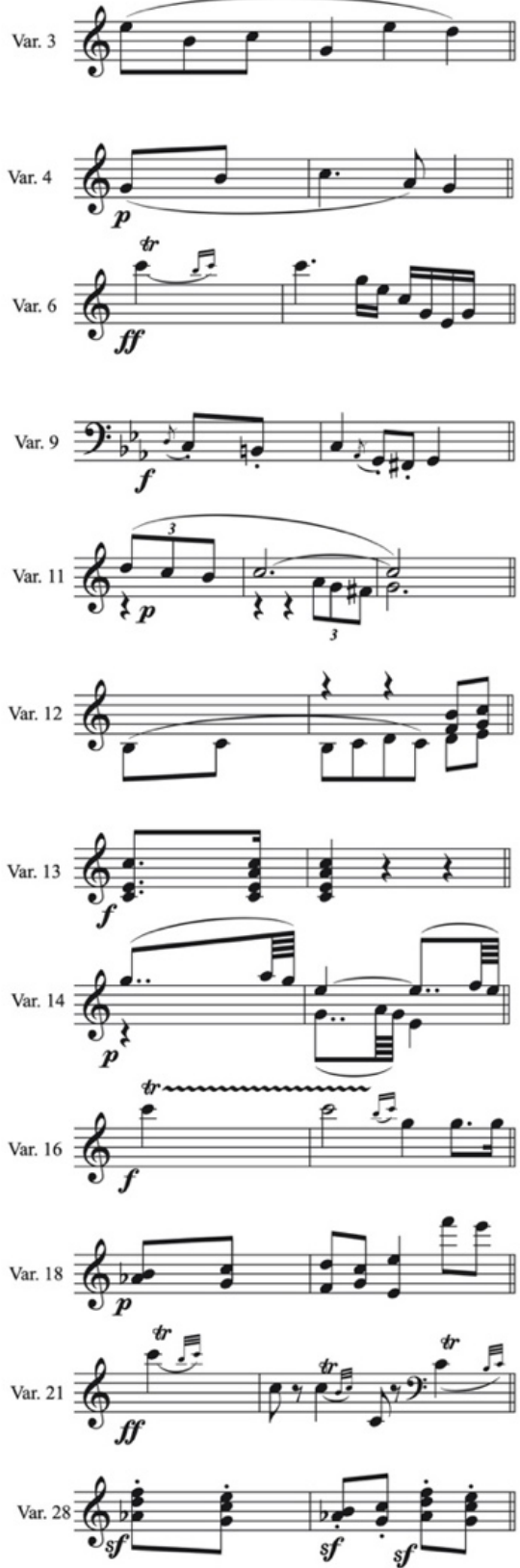

b) derivações dos motivos $b \mathrm{e} c$
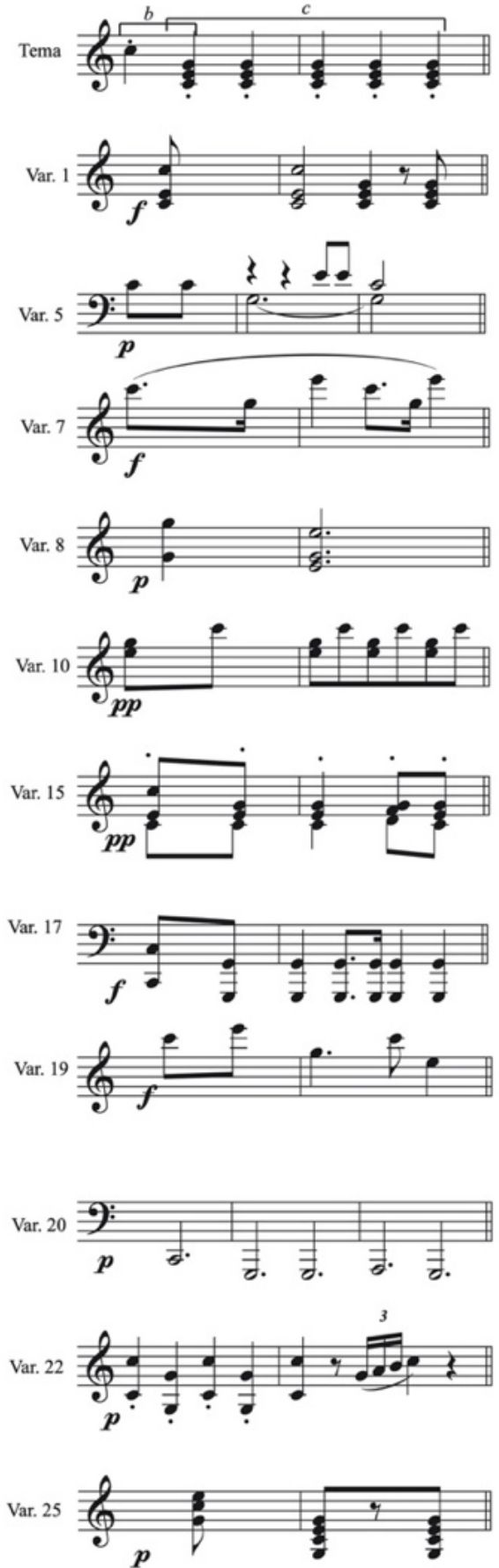


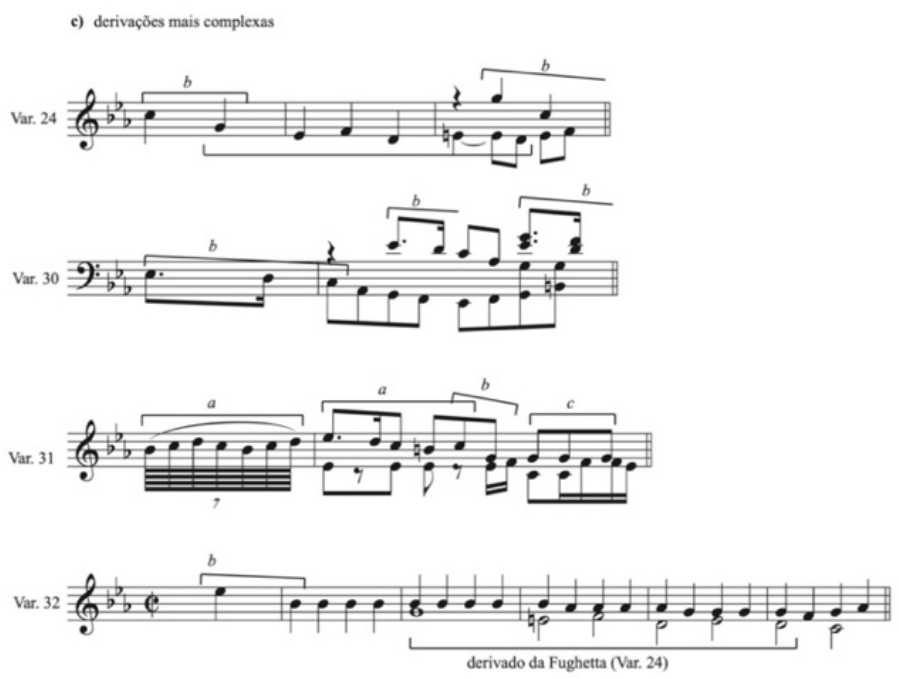

Exemplo 11a-c: Beethoven, Variações Diabelli, Op. 120, Tabela de correspondências motívicas.

Para concluir esta seção cabe mencionar que a noção de variação progressiva ainda envolve uma série de procedimentos formais que Schoenberg aborda em The Musical Idea. Estes procedimentos podem ser classificados em duas categorias: a. os que propiciam a extensão das estruturas musicais; e b. os que propiciam a terminação formal. Na primeira encontram-se as técnicas de conexão (Anschluss Technik): 1. uso de contraste; 2. ligação (welded together); 3. justaposição; 4. uso de uma característica rítmica ou intervalar da frase precedente; 5. harmonias anacrústicas. Também se inclui aqui o procedimento de modelo e sequência. Na segunda categoria encontram-se: 1. liquidação e dissolução que são compostas por sua vez por condensação e intensificação, i.e. um agrupamento do conteúdo motívico em menor espaço de tempo; e redução, i.e. eliminação de conteúdo motívico. Finalmente, a tendência das menores notas também pode ser incluída nos procedimentos formais de encerramento formal. Estes procedimentos de encerramento formal são importantes no conceito de variação progressiva uma vez que servem para delimitar a segmentação formal, seja em pequena, média ou larga escala (cf. Dudeque 1999; e Dudeque 2005, p. 154-162).

\section{Prosa Musical}

Heinrich Besseler, em 1953, utilizou o termo "prosa musical" para definir o estilo melódico do canto gregoriano, i.e., um estilo que "constantemente 
produz algo novo" (Besseler 1953, p. 224 apud Dahlhaus 1987, p. 105). Ele esclarece que

Prosa é um antigo termo latino que significa discurso ilimitado, o qual procede de uma maneira simples e direta: oratio prorsa ou prosa. A prosa cotidiana é livre em todos os sentidos. Ela constantemente inventa algo novo. O mesmo também é verdadeiro em relação à prosa literária. Ela geralmente evita o que é regular e ordenado; evita repetições verbais, assonância e rimas; ela até mesmo evita uma similaridade muito grande na construção de sentenças, uma vez que esta pode dar a impressão de um estilo culto com paralelismos rítmicos (Besseler 1953, p. 224 apud Dahlhaus 1987, p. 105).

Forma musical constituída por elementos não recorrentes, desenvolvimento temático contínuo, contrastes abruptos de andamento e caráter, e construção de frases assimétricas caracteriza obras que tenham "prosa musical" como seu principal procedimento composicional. São características importantes que sugerem um estágio distinto no desenvolvimento motívico e temático que caracteriza variação progressiva, mas que resulta em um estilo de composição musical que privilegia um processo contínuo, e não gradual, de desenvolvimento do material musical.

Stein, ao relatar sua percepção da música de Max Reger (1873-1916), observa que nas obras mais avançadas do compositor a assimetria, por exemplo, de sentenças com três frases de dois compassos, meio compasso, e um e meio apontam para uma característica da música do futuro na época e para uma nova maneira de construção temática. Ele resume que

O propósito das estruturas rítmicas simétricas é moldar pensamentos musicais em formas memoráveis. A regularidade facilita a percepção, repetição rememora. O efeito formal é análogo àquele do verso. Mas, atualmente, outros meios de expressão tornaram-se inteligíveis. Linguagem livre é preferível à fala métrica, e música há que privilegiar a prosa musical (Stein 1953, p. 40).

Brinkmann, por sua vez, resume características da obra de Reger que fazem parte da avaliação desta música no século XXI. Ele lista: a) a linguagem harmônica que se aproxima ao limite do tonalismo; b) a estrutura composicional com o contraponto como fator estabilizador; c) espaço musical como polifonia da superfície sonora (Brinkmann 2004, p. 636). Mas o ponto mais importante no presente contexto é a discussão sobre prosa musical como uma linguagem musical que imita a liberdade métrica semelhante àquela em um recitativo. 
Alban Berg também observa que características da música de Schoenberg tais como assimetria de frases, falta de repetições literais e de estruturas correspondentes fazem parte da dificuldade de entendimento deste tipo de música, a de Schoenberg e a de Reger (vide Brinkmann 2004, p. 636-637). Ademais, Berg lista as seguintes características, entre outras, como pertencentes a esse estilo musical: 1. multiplicidade na harmonia; 2. construção de temas assimétricos e livres; 3. a arte da variação afetando o trabalho temático (motívico) (Berg 1965, p. 202). Assimetria nas formas de apresentação temática e nas estruturas motívicas são características notáveis em música baseada em prosa musical.

Variação progressiva e prosa musical são resultados de desenvolvimento motívico de acordo com as proposições teóricas de Schoenberg. A primeira consiste em um processo gradual de desenvolvimento motívico que origina novas ideias musicais. A diferença entre prosa musical e variação progressiva reside na omissão do processo gradual e de estágios intermediários entre as variações motívicas geradas de uma Grundgestalt e que originam novas ideias musicais. Schoenberg toma como ponto de partida da sua argumentação sobre prosa musical a observação da formação de estruturas e frases assimétricas em obras de compositores do passado. Em particular, ele considera Mozart e Brahms como os compositores mais proeminentes neste aspecto. Assim, para Schoenberg, prosa musical é relacionada ao desenvolvimento direto e contínuo de ideias musicais sem a necessidade de um processo gradual de desenvolvimento característico de variação progressiva. $O$ resultado são estruturas caracterizadas pela assimetria métrica de seus motivos e frases. Ao tentar definir tal procedimento Schoenberg declara em seu ensaio "Brahms the Progressive" (1947):

Grande arte deve prosseguir em direção à precisão e à brevidade. Ela pressupõe uma mente alerta de um ouvinte educado que, em um único ato de reflexão, inclua todos os conceitos todas associações pertencentes ao sistema. Isso possibilita ao músico escrever para as mentes superiores, não somente fazendo o que a gramática e o idioma requerem, mas, em outros aspectos, dando a cada sentença o sentido da plena pregnância de uma máxima, de um provérbio, de um aforismo. Isto é o que prosa musical deveria ser - uma apresentação direta e objetiva de ideias, sem quaisquer artificialismos, e meros preenchimentos e repetições vazias (Schoenberg 1975, p. 414-415). 
Frisch resume prosa musical como caracterizando um tipo de música que não privilegia a regularidade de frases e simetria, e que de fato, "não se adequa a modelos regulares e pré-definidos ou previsíveis". Finalmente, "variação progressiva e prosa musical são, em determinado sentido, duas maneiras diferentes de descrever o mesmo processo. Variação progressiva - o princípio de acordo com o qual ideias são variadas continuamente - provê a gramática pela qual prosa musical é criada" (Frisch 1984, p. 8-9). Assim, a característica de assimetria seria apenas um subproduto de prosa musical (Dahlhaus 1987, p. 105).

A ilustração que Frisch se refere é o exemplo do tema do Andante moderato do quarteto para cordas, Op. 51, n. 2, de Brahms que Schoenberg analisa como prosa musical. A identificação de frases assimétricas dentro do período mostra que não há relação entre o antecedente (c. 1-4) e consequente (c. 5-8). Schoenberg tenta demonstrar que a unidade da passagem se baseia somente nas similaridades motívicas entre os elementos internos. Assim ele esclarece que o motivo $a$, uma segunda ascendente, é o motivo básico a partir do qual os outros são derivados, ele descreve:

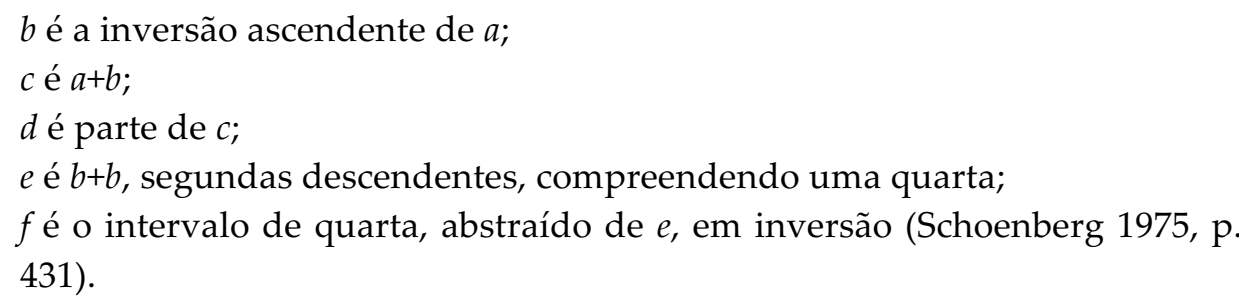

Schoenberg segue relatando as frases identificadas e sua construção motívica interna. A irregularidade no tamanho das frases proporcionou a Schoenberg a oportunidade de propor uma reinterpretação métrica da passagem com o objetivo de tornar mais clara a assimetria entre as frases (vide Exs. 12a-b). Schoenberg também alerta que argumentações de que o intervalo de segunda é comumente encontrado em qualquer tema e, portanto, não constituiria material temático. No entanto, sua análise permite que entendamos o trecho como composto por um antecedente e um consequente quase que simétricos, reinterpretação exposta na sua releitura métrica do tema. $\mathrm{O}$ antecedente compreendendo os compassos de 1 a 5.2 projetando a I (Lá maior) até sua V (c. 5.2), e o consequente completando uma cadência V-I no c. 7 e voltando à dominante (V) nos dois últimos tempos do c. 8, deixando, portanto, a estrutura tonalmente aberta e permitindo sua continuação ininterruptamente (Exs. 12a-b). 
MUSICA THEORICA Revista da Associação Brasileira de Teoria e Análise Musical 2020, v. 5, n. 2, p. 165-206 - Journal of the Brazilian Society for Music

a)
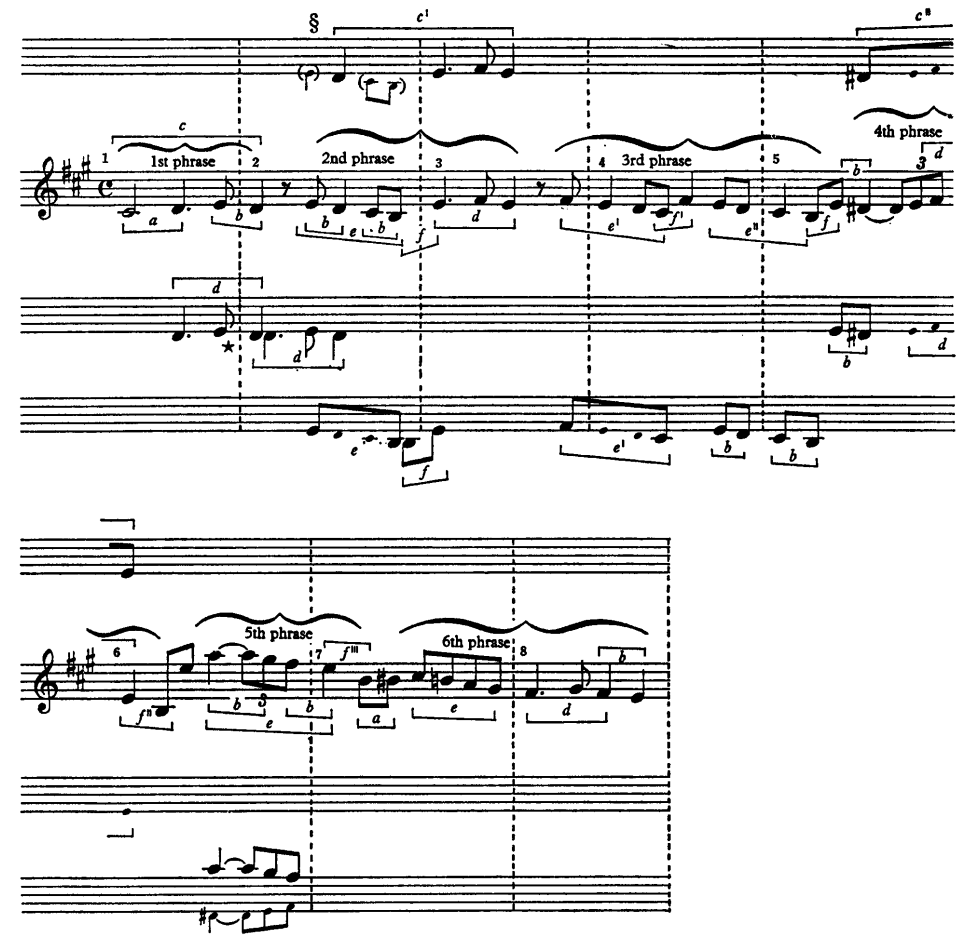

b)

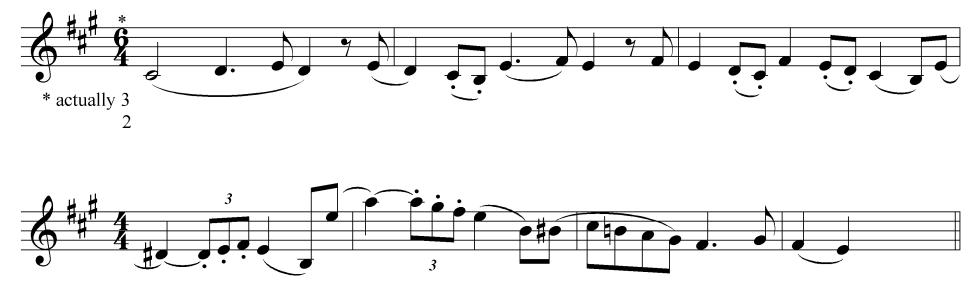

Exemplo 12a-b: Schoenberg, Style and Idea, Ex. 46, p. 430 e Ex. 50, p. 435, Brahms, Quarteto de cordas, Op. 51, n. 2, Andante moderato.

Outra ilustração extraída do texto de Schoenberg (1975, p. 426), mostra o tema de "Der Abschiede", último movimento de Das Lied von der Erde, de Mahler. Schoenberg comenta: "todas as unidades variam grandemente em forma, tamanho e conteúdo, como se elas não fossem partes motívicas de uma unidade melódica, mas palavras, cada qual com seu propósito dentro de uma sentença" (p. 426) (vide Ex. 13). 


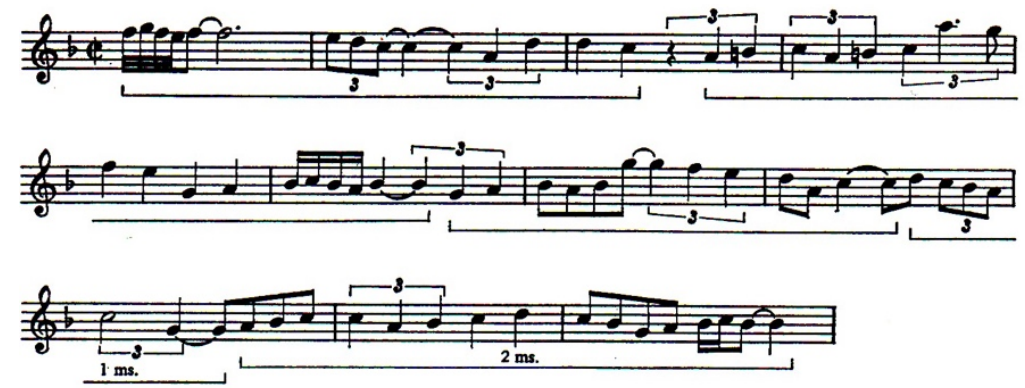

Exemplo 13: extraído de Schoenberg (1975), Style and Idea, p. 426, Ex. 41; G. Mahler, "Abschiede", Lied von der Erde.

Em certo sentido Schoenberg, ao qualificar cada unidade melódica com função própria, está relacionando prosa musical à "melodia infinita" (unendlich Melodie) de Wagner, a qual mantém que todas as notas na harmonia e na melodia tem importância expressiva, e enfatiza o desenvolvimento constante do material musical. No entanto, devemos lembrar que o termo "melodia infinita" surge em Zukunftsmusik de Wagner em 1860, e que é utilizado pelo compositor em um contexto em que ele distingue entre passagens musicais "melódicas", que são constantemente expressivas e significativas, e passagens "não melódicas", que consistem em fórmulas pré-definidas e nada "significam". Portanto, há uma implicação mais estética do que técnica, ou seja, significa que toda figura musical deve conter uma "ideia" real e não simples preenchimentos e repetições de passagens. O objetivo de Wagner é de uma continuidade musical constante com significado musical em todos os detalhes (Deathridge e Dahlhaus 1984, p. 115116). Grey, por sua vez, sugere que a abertura de Tristão e Isolda representa "um paradigma do tipo de processo evolucionário, linear e inconsútil sugerido pelo termo" (Grey 1995a, p. 262). O Ex. 14a ilustra a frase inicial e as figuras motívicas marcadas como $a$ e $b$. No Ex. 14 b, c. 8-11, mostra a frase 1 variada e a figura motívica $b$ fragmentada. Após, há uma intermediação motívica, Ex. 14c, que começa com um fragmento de $b 1$ e que gera a frase sobreposta que produz uma progressão V-VI (em Lá menor), uma cadência de engano. Melodicamente produz a sobreposição do final da intermediação no c. 17 (Sił-Láł) com o início da frase seguinte. A frase 2 é constituída pelos motivos $c 1$ e $c 2$. O Ex. 14d mostra a terceira frase (c. 25-26) onde ocorre o reordenamento dos motivos, sendo assim apresentados os motivos $c 2-c 1$ seguidos de um fragmento de $b$. Este trabalho 
MUSICA THEORICA Revista da Associação Brasileira de Teoria e Análise Musical 2020,

v. 5, n. 2, p. 165-206 - Journal of the Brazilian Society for Music

motívico-temático apresenta o tipo de melodia infinita com a fluência desejada por Wagner.
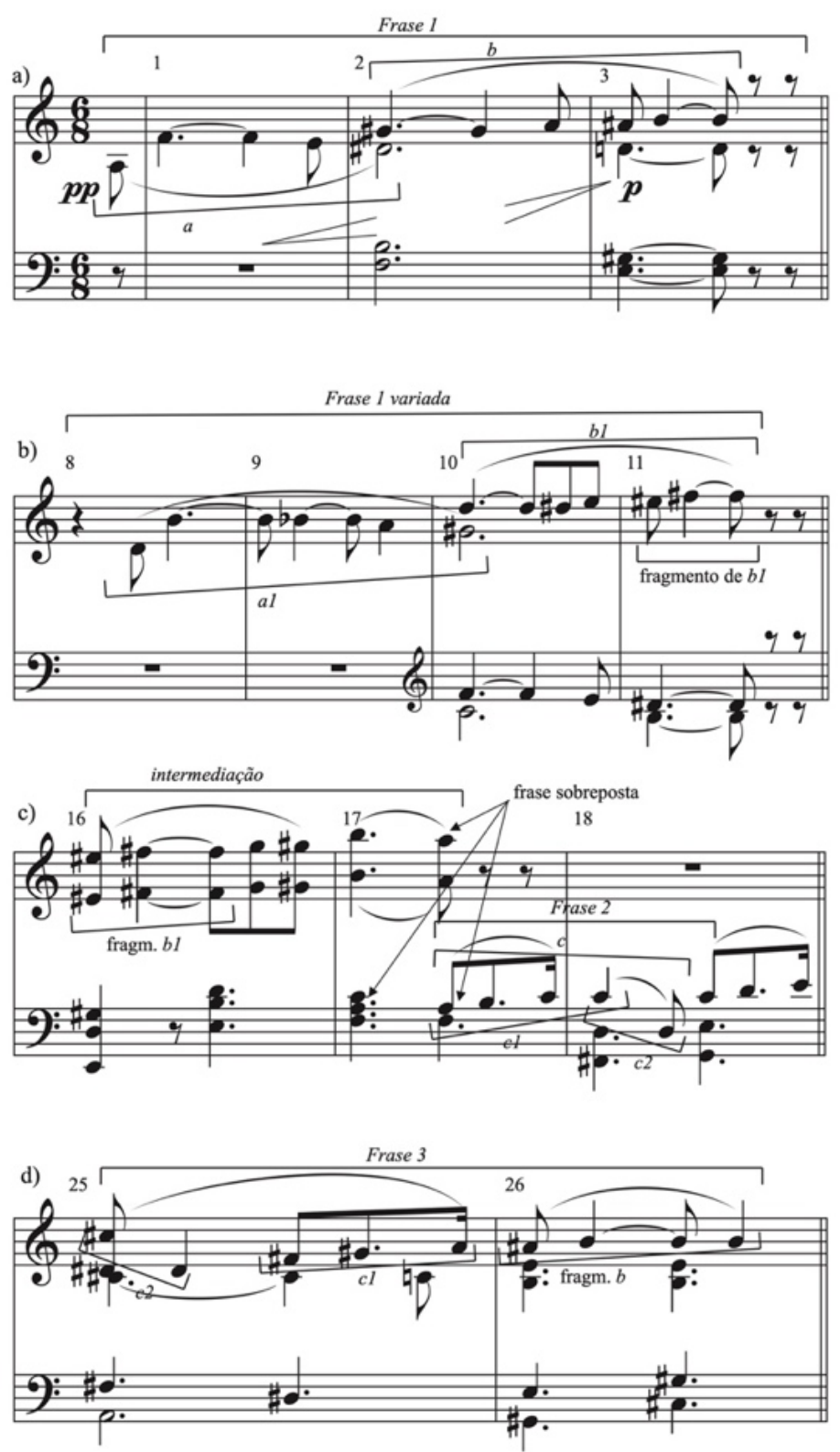

Exemplo 14a-d: R. Wagner, excertos de "Abertura" de Tristão e Isolda.

A definição de prosa musical proposta por Schoenberg se aproxima da caracterização de melodia infinita de Wagner que pretendia estabelecer uma relação estética entre seu Tristão e Isolda e a música sinfônica de Beethoven. Nos dois casos, "as ideias melódicas (motivos) são organizadas num discurso musical de contínua eloquência, unindo o intento estrutural ao expressivo, enquanto evita o "recheio" da fraseologia musical convencional" (Grey 1995a, p. 268). 
Ademais, as consequências para a forma musical são inevitáveis. Grey esclarece que “Wagner estende a técnica da sua prosa musical ou 'melodia infinita' - o entrelace de frases com motivos condutores (leitmotives), gerados pelo texto ou pela música - para os níveis mais gerais da forma, de maneira que melodias infinitas geram 'infinitos', inconclusivos, designs formais centrífugos" (Grey 1995b, p. 303).

Um exemplo extraído da parte do violoncelo da "Serenade" de Pierrot Lunaire Op. 21, de Schoenberg, é elucidativo (vide Ex. 15). As frases musicais consistem em uma alternância constante entre unidades de um e de dois compassos (Schoenberg 1975, p. 428). Notável no exemplo de Schoenberg é a variedade e diversidade dos eventos musicais, sendo cada uma das frases identificadas como única e sem relação aparente entre si. Assim, pode-se classificar no Ex. 15 cada frase como uma figura motívica diferenciada.

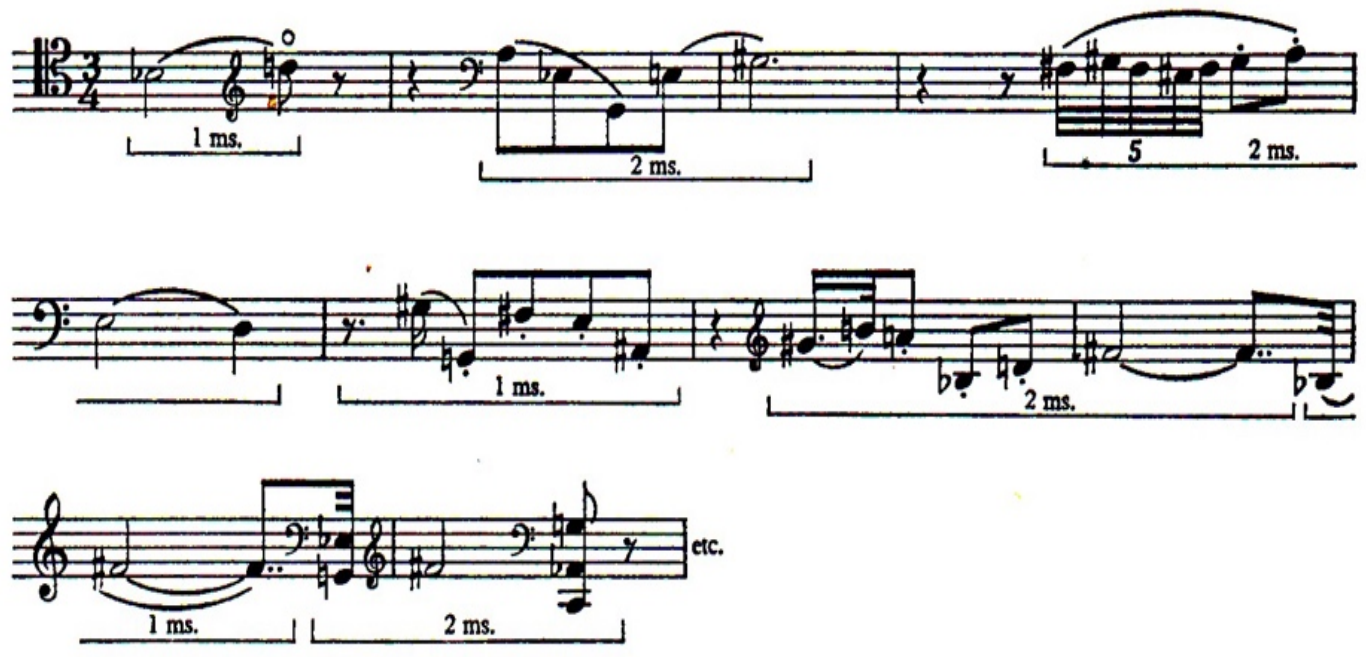

Exemplo 15: Schoenberg, Style and Idea, p. 428, Ex. 45; A. Schoenberg, excerto da parte do violoncelo, "Serenade", Pierrot Lunaire, Op. 21.

O tipo de música composta por Schoenberg que privilegia "prosa musical" como um princípio fundamental de composição recebeu uma reflexão por parte do compositor e expressa em uma carta a Busoni datada de agosto de 1909. Schoenberg argumenta a favor de - e comenta sobre - seus planos de compor música por puro instinto, livre de conotações de regularidade, coerência motívica e simetria, e com uma constante alternância de atmosferas. Ele escreveu: 
MUSICA THEORICA Revista da Associação Brasileira de Teoria e Análise Musical 2020, v. 5, n. 2, p. 165-206 - Journal of the Brazilian Society for Music

Eu procuro por uma libertação completa de todas as formas de todos os símbolos de coesão e de lógica.

\section{Assim:}

chega de "trabalho motívico."

chega de harmonia como

o cimento ou tijolos de um edifício.

Minha música deve ser

breve.

Concisa! Em duas frases: não ser construída, mas sim "expressada"!!

Ela deve ser uma expressão de sentimento, como nossos sentimentos, o qual nos traz contato com nosso subconsciente, realmente são, e não uma falsa criança de sentimentos e de "lógica consciente."

$\cdots$

Por enquanto eu completei a terceira peça para piano [Op. 11, n. 3] (antes da qual eu escrevi uma peça orquestral)...[Op. 16, n. 4].

(in Busoni 1987, p. 389)

Esta carta parece ser uma descrição do tipo de linguagem musical que Schoenberg adotou com as peças de atonalidade livre do início do século XX e em particular na Peça para piano Op. 11, n. 3.7

A linguagem musical no Op. 11, n. 3 de Schoenberg tem sido objeto de discussão de vários analistas. Análises descrevem a falta aparente de uma lógica motívica e a falta de elementos recorrentes desafiam a compreensão da obra. Este é o ponto de vista externado por Samson (1977) que argumenta que

nenhuma organização sistemática da linguagem melódica e harmônica pode ser encontrada sem forçarmos a questão, esta subdivisão em seções componentes de durações variáveis, caracterizadas por tipos particulares de material rítmico e textural articulados por pontos cadenciais claramente definidos, é de importância crucial na tentativa de se entender a estrutura geral [da obra] (Samson 1977, p. 183).

Mesmo com a identificação de pontos cadenciais de articulação na obra, a descrição de Samson não provê uma explicação de como a música é articulada em momentos tão contrastantes. Por sua vez, Simms argumenta que não ocorre

\footnotetext{
${ }^{7}$ Haimo argumenta que esta carta descreve "apaixonadamente" a impressão de Schoenberg a respeito do Quarteto para cordas, Op. 5 de Anton Webern, sobre o qual ele pode ter tomado conhecimento no final de julho ou início de agosto de 1909 (vide Haimo 2006, p. 342).
} 
variação progressiva na peça e, portanto, a coerência do discurso musical é diferente daquela tradicional e relacionada a este procedimento composicional. Ele argumenta que a coesão nesta peça é de outra ordem e baseada em gestos expressivos e figuras (Simms 2000, p. 66-68). Já Haimo (2006, p. 332-344) associa a mudança radical na linguagem musical de Schoenberg às obras da mesma época de Anton Webern, em particular as Fünf Sütze für Streichquartett Op. 5, o que sugere uma correspondência entre os processos composicionais dos dois compositores. Haimo resume dois pontos importantes sobre o Op. 11, n. 3: a) é uma extensão da técnica de variação progressiva; b) o uso de contraste para enfatizar graus de semelhança (Haimo 2006, p. 343). Na discussão sobre prosa musical comentada anteriormente, a primeira proposição de Haimo é reconsiderada e argumenta-se que prosa musical seja o princípio composicional adotado por Schoenberg em algumas de suas obras, incluindo aí o Op. 11, n. 3. Quanto à segunda observação, ela é válida uma vez que este é o principal procedimento articulatório em obras que sejam originadas através de procedimentos formais tradicionais da teoria analítica de Schoenberg, tais como, liquidação motívica, condensação e intensificação. ${ }^{8}$

Os eventos musicais exemplificados na peça para piano Op. 11, n. 3 de Schoenberg, ilustrados nos Exs. 16a-f, esclarecem que certas semelhanças existentes entre figuras motívicas não geram um desenvolvimento motívicotemático a ponto de caracterizar variação progressiva. Nos exemplos são apresentadas passagens subsequentes na peça, em sentido cronológico. Nos Exs. $16 \mathrm{a}-\mathrm{b}$ os eventos apresentam material motívico relacionado, mas não semelhante, a relação possível de ser percebida ocorre a nível rítmico apenas. As figuras $A \mathrm{e}$ $A^{\prime}$, marcadas com colchetes no Ex. 16a, têm correspondência rítmica mas não melódica. A figura motívica $A$ compreende uma sequência de graus conjuntos descendentes, Lá ${ }^{2}-$ Sol\# ${ }^{2}$ e Ré ${ }^{2}-$ Dó$^{2}$, já a figura $A^{\prime}$ compreende repetição de notas e saltos, Ré-Ré2-Dó\#-Lá1. A figura $A^{\prime \prime}$ (Ex. 17b) apresenta novamente uma correspondência rítmica, mas também apresenta inversão de direcionamento melódico (c. 2.2-3) e até mesmo compressão de valores rítmicos no c. 3, tornandose, portanto, distinta da inicial $(A)$. Segue no Ex. 16c um gesto cadencial de encerramento de seção. Não há qualquer correspondência motívica aqui, o

\footnotetext{
${ }^{8}$ Sobre procedimentos formais na teoria schoenberguiana, vide Dudeque 2005, p. 154-162.
} 
compositor apresenta uma nova ideia que se encerra com o intervalo de trítono nas duas últimas notas (Ré\#-Lá). O próximo evento é de transição e caracterizado pela diminuição da densidade da textura musical (Ex. 16d). No c. 5 os acordes são densos e logo seguidos pelas figuras com tercinas de semicolcheias no c. 6 que promovem o afrouxamento da densidade da textura. A transição se encerra com as figuras em semicolcheias no c. 7 na fermata. Seguem, nos Exs. 16e e 16f, dois segmentos: o primeiro de transição, o segundo, cadencial que encerra a primeira seção da peça. Novamente não se encontra relação motívica. Aliás toda esta primeira seção da peça é caracterizada por um fluir de ideias musicais contrastantes, assimétricas e que se sucedem rapidamente. Apesar dos gestos cadenciais e de transição, o discurso musical é caracterizado como prosa musical.
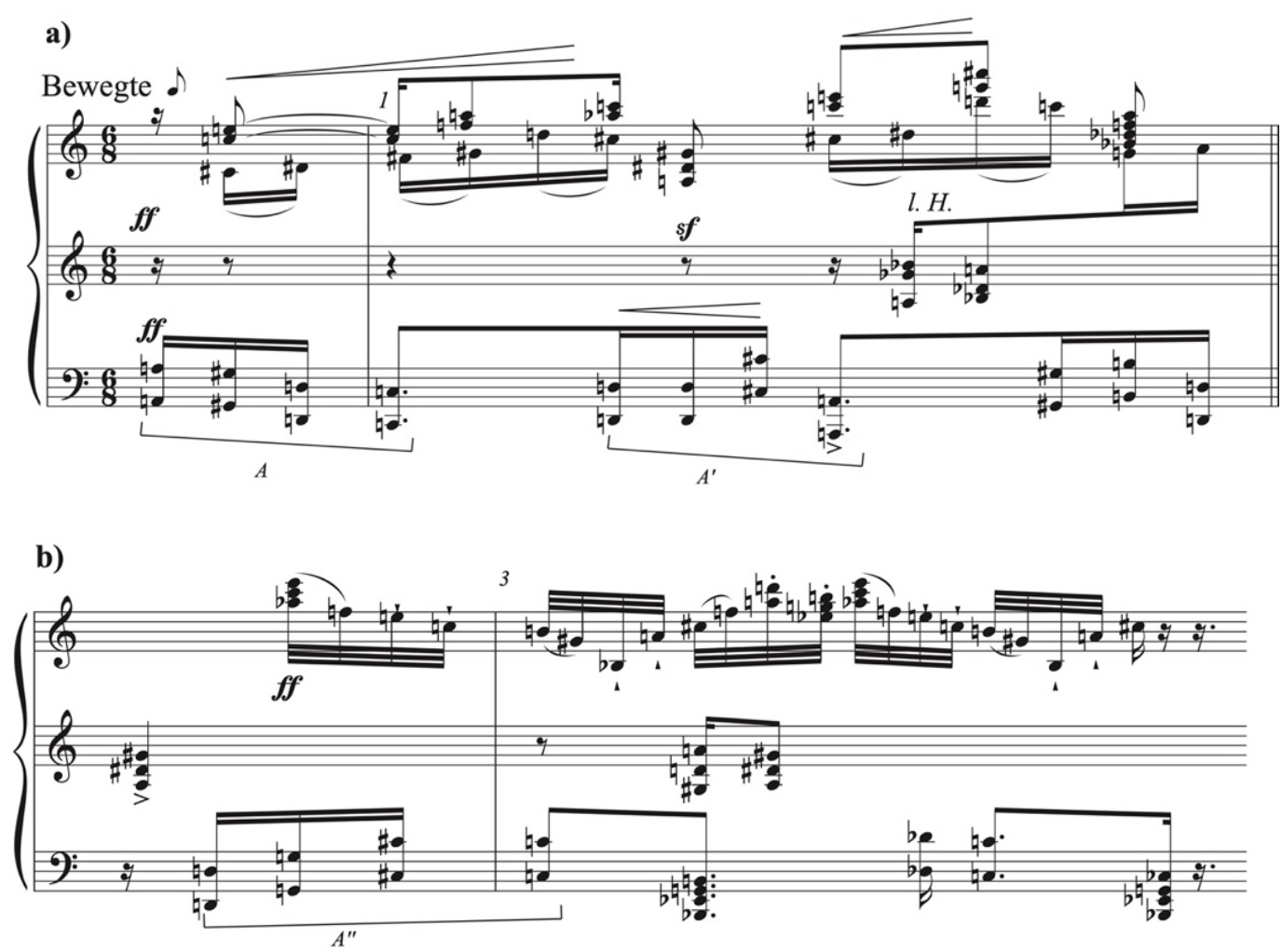

c)

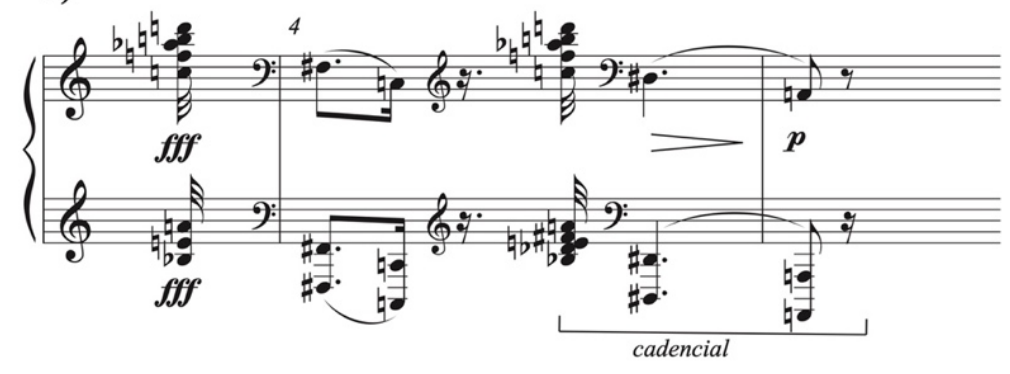



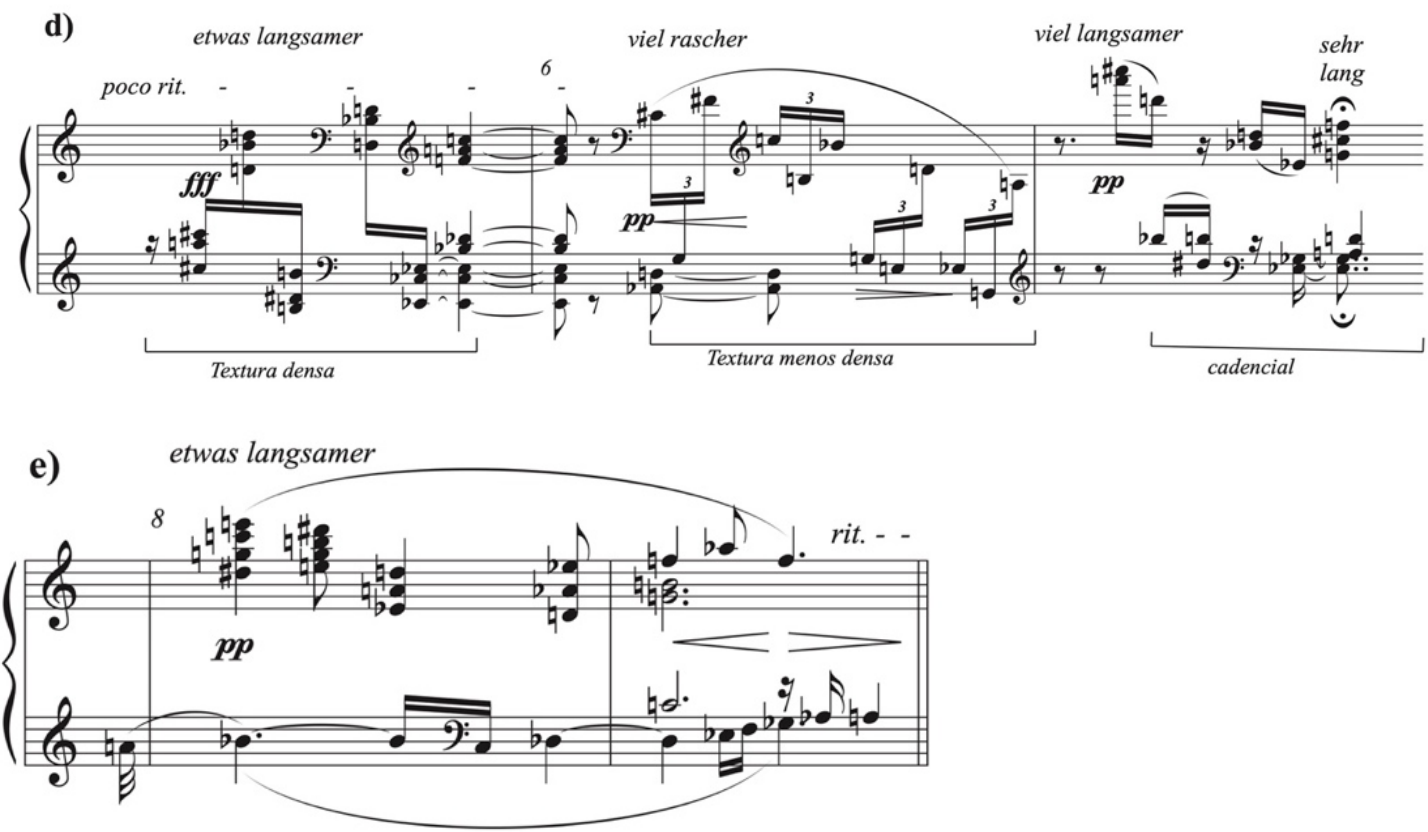

f)

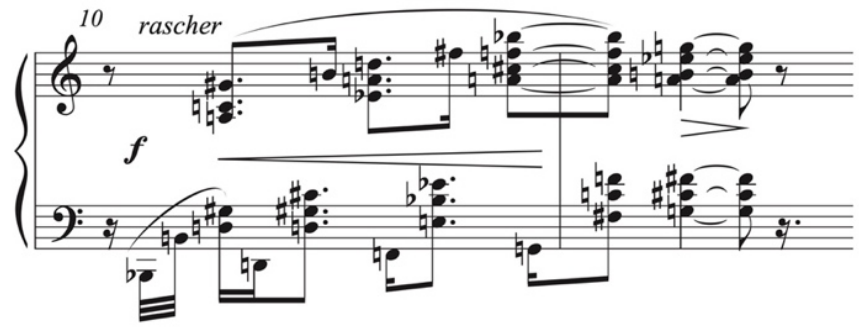

Exemplo 16a-f: excertos de A. Schoenberg, Peça para piano Op. 11, n. 3.

Outro exemplo de Schoenberg é a peça n. 5 das Fünf Orchesterstücke, Op. 16, Das obligate Rezitativ, compostas em 1909. O título da peça foi atribuído pelo próprio compositor em seu diário datado de 28 de janeiro de 1912. Ali o compositor atribui os títulos para as demais peças do Op. 16, mas mais importante é a anotação entre parênteses para a peça n. 5: "V. Das obligate (talvez o melhor seja 'completamente desenvolvida' ou 'infinita') Rezitativ"' (Schoenberg 1912 in Jenkins (ed.) 2016, p. 189). Adicionalmente, Dahlhaus relata que Schoenberg, para justificar seu título, associa recitativo a uma expressão musical livre quando declara "Eu consegui apresentar e justificar minha ideia sobre o 'recitativo obbligato' de maneira relativamente clara. Mas não completamente. A ideia é mais profunda: se exprime o inexpremível na forma livre" (apud Dahlhaus 1987, p. 144). A denominação de "infinita”, mencionada no diário de Schoenberg, 
remete também à "melodia infinita" de Wagner. Aliás, cabe ressaltar as características do início da Op. 16, n. 5. No Ex. 17 encontram-se os primeiros compassos da peça. Se observarmos as vozes principais (Hauptstimme), indicadas pelo próprio compositor, notaremos uma constante assimetria e diferentes motivos. Por exemplo, a partir da anacruse do primeiro compasso, Schoenberg marca um motivo, na voz mais aguda, Mił-Mib e na parte inferior um semitom descente de Láł-Sol\#. A partir do c. 2, as duas frases da voz superior, iniciam com a mesma figura (Réł-Mił-Fáł-Sił) mas cada qual conclui de maneira diferente e geram percepções distintas. Se observarmos todo o conjunto de vozes principais e secundárias, não encontraremos figuras motívicas semelhantes, ou seja, cada uma das vozes é composta de maneira única e proporcionando um desenvolvimento motívico contínuo que sugere um caráter atemático (ou "amotívico"). Dahlhaus resume as características do Op. 16, n. 5:

a sintaxe é assimétrica, a estrutura melódica e polifônica atemática e a forma não-repetitiva, sem a coerência interna de uma peça que é determinada por um texto ou programa. Invés, as Hauptstimme se desenvolvem livremente como uma cadeia constante de novas ideias musicais (Dahlhaus 1987, p. 146).

Das obligate Rezitativ

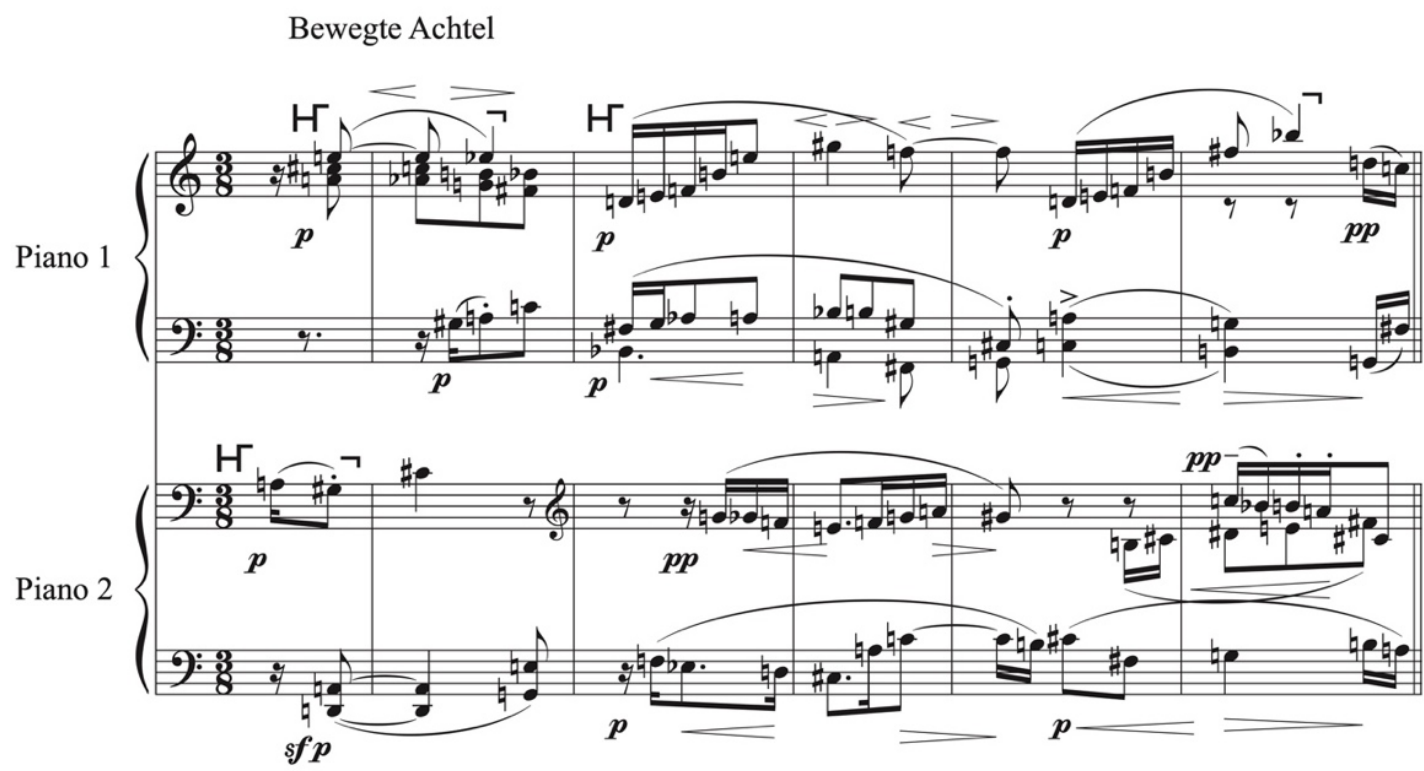

Exemplo 17: excerto de A. Schoenberg, Fünf Orchesterstücke, Op. 16, Das obligate Rezitativ, c. 1-5, redução para dois pianos de Anton Webern.

Erwin Schulhoff (1894-1942), em algumas de suas composições de 1919_ 1921, utilizou prosa musical como um procedimento estrutural. Por exemplo, em 
Elf Inventionen de 1921, o compositor apresenta uma música extremamente concentrada, com uma métrica fluída, na maior parte sem barras de compasso. Esta parece ser uma aplicação do princípio de prosa musical que havia sido formulado por Max Reger, com quem Schulhoff estudou composição entre 19081910 no Conservatório de Leipzig. O assunto, prosa musical, também era frequente no círculo de Schoenberg na época. A intensa correspondência sobre o assunto entre Schulhoff e Alban Berg levou este último a escrever que “há muito paramos de considerar as barras de compasso como o meio de ligação da melodia e de frases; basta olhar para minhas primeiras obras para clarinete, ou as últimas obras de Schoenberg - todas podem ser interpretadas sem qualquer fórmula de compasso" (in Haas, 2013, p. 121). A segunda invenção, das Elf Inventionen, ilustra a prosa musical de Schulhoff (Ex. 18). O primeiro aspecto a ser notado é a liberação completa da métrica e das marcações de barras de compasso. As pontuações são marcadas por pausas, algumas prolongadas por fermatas. Em termos de trabalho motívico não há repetições que possam ser relacionadas, cada figura motívica, cada evento, é único. Os eventos estão numerados de 1 a 9 e são sobrepostos ou subsequentes. A figura 1 é composta por um arpejo Sol-Dó-Fá\# seguido pela sua prolongação através do ligado. Concomitantemente o evento 2 inicia no sistema inferior com um arpejo de quartas justas descendentes e em semicolcheias. $\mathrm{O}$ evento 3, em semicolcheias, inicia com um arpejo ascendente de quartas e se encerra com a nota Fá\# repetida. Sobreposto a esta repetição está o evento 4 que confirma o arpejo de quartas justas como um elemento importante na peça. Essa primeira "frase" se encerra com a pausa prolongada pela fermata. O evento 5 pode ser visto como uma união dos eventos 1 e $3(1+3)$ e não caracteriza, por isso, uma repetição do evento inicial. Seguem os eventos subsequentes 6 e 7, sendo esse último sobreposto, no seu final, ao evento 8 que tem a sobreposição do curto evento 9. Ao final da peça há uma breve recapitulação com o evento 1 . O fluxo constante de ideias musicais distintas é baseado na elaboração motívica-temática constante e cria a sensação de fluência musical. 


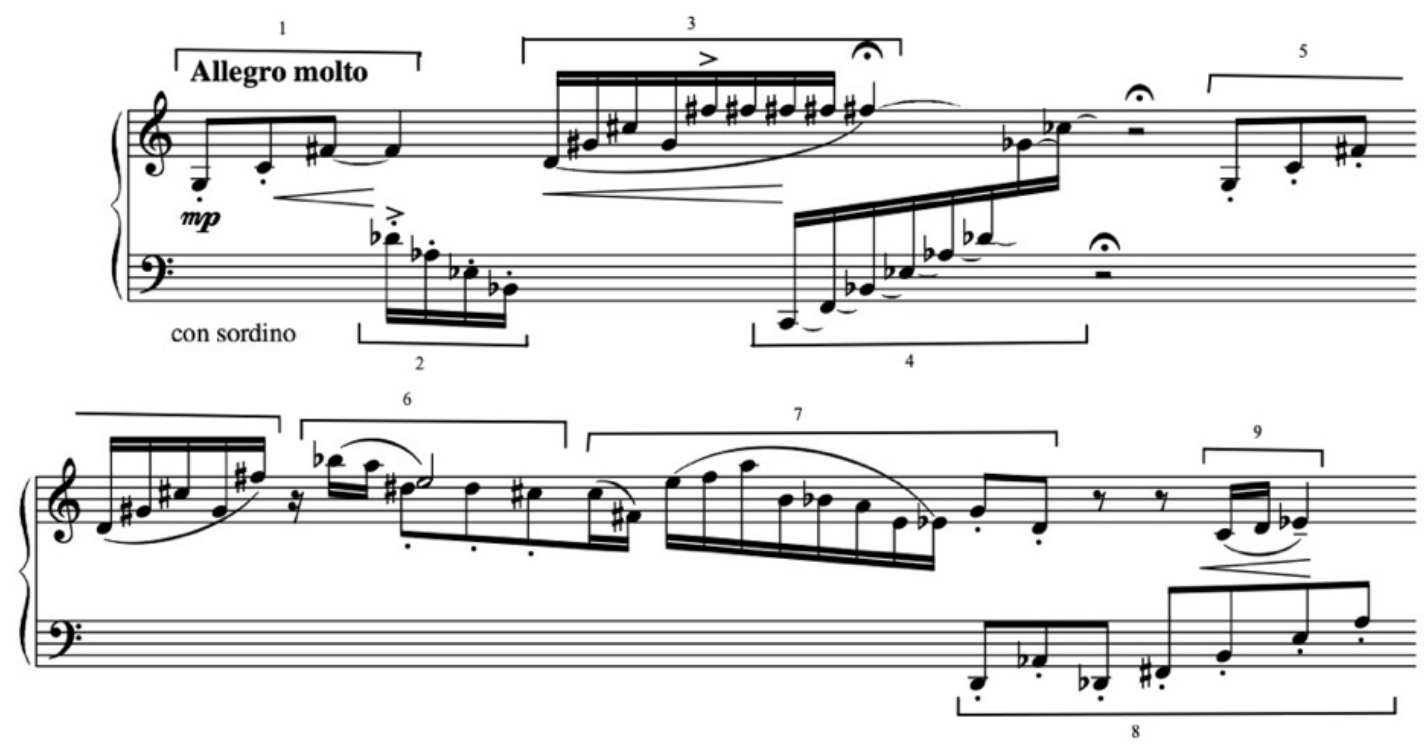

Exemplo 18: excerto de E. Schulhoff, Elf Inventionen, n. 2.

Finalmente o Ex. 19 mostra o início da canção para voz e piano de Glauco Velasquez (1884-1914), Alma minha gentil (1913), aqui utilizada a orquestração de Luciano Gallet, que tem prosa musical como princípio motívico-temático estrutural na obra. A ligação de Velasquez às ideias da música germânica do romantismo, e por conseguinte com as ideias de Schoenberg, se dá através de seu professor de harmonia no Instituto Nacional de Música Frederico Nascimento em 1903. Nascimento, amigo de Alberto Nepomuceno, foi influente no meio teórico da época. Nepomuceno, por sua vez, esboçou uma tradução do Harmonielehre de Schoenberg em 1916. Também importante é observar que a música romântica germânica do final do século XIX foi bastante favorecida pela obra de Leopoldo Miguez, seja como compositor ou como diretor do INM. ${ }^{9}$ Portanto, a linguagem musical de Velasquez apresenta pontos de contato com tendências composicionais importantes da época. No trecho apresentado no Ex. 19 foram identificadas várias figuras motívico-temáticas que são mostradas pelos colchetes e listadas de $a$ a $m$. Observa-se também que algumas destas figuras são originais somente da orquestração de Gallet (marcadas como Gallet). Nos c. 1-2 há a identificação da figura $a$ porém com variações: $a$ (Gallet) corresponde a forma inicial apresentada na flauta; a1 é a versão apresentada pela voz; e $a 2$ é uma imitação variada apresentada pelo oboé. Nenhuma das três é repetida literalmente. Juntamente com as figuras motívicas $a$ e a1 são sobrepostas as

\footnotetext{
${ }_{9}^{9}$ Para relatos destas relações vide Coelho de Souza 2006, e Dudeque 2005.
} 
figuras e e $f$ nas cordas. As figuras subsequentes, c. 2-4, são completamente independentes entre si, ou seja, nenhuma apresenta qualquer relação motívica de repetição. Talvez as figuras $b$ (voz) e $c$ (oboé, Gallet) possam ser distantemente relacionadas através de imitação (bastante) livre. Porém, as figuras $g$ e $h$, nas cordas, são independentes e originais de Gallet. A figura $d$ (voz) é parcialmente dobrada pela flauta (a terminação é distinta). Por fim, nos c. 7-8, há uma profusão de ideias distintas e independentes sobrepostas: $k$ (voz), $j, l$ e $i$ (cordas, adicionadas por Gallet) e $m$ (oboé). O restante da canção é articulado através de cadências de acordo com os versos da poesia. Há uma ou outra repetição motívica que não prejudica a constante fluência na apresentação de figuras motívicas novas. Pode-se, portanto, sugerir que prosa musical esteja de certa maneira imbuída como um princípio composicional nesta obra de Velasquez. As adições de Gallet na orquestração da canção certamente enfatizam o caráter de prosa musical que predomina na versão original da canção e contribuem na percepção da obra como tal. Ainda deve-se notar que a observação analítica de Schoenberg sobre prosa musical pode extrapolar o repertório analisado pelo compositor, e esta canção é ilustrativa disso.

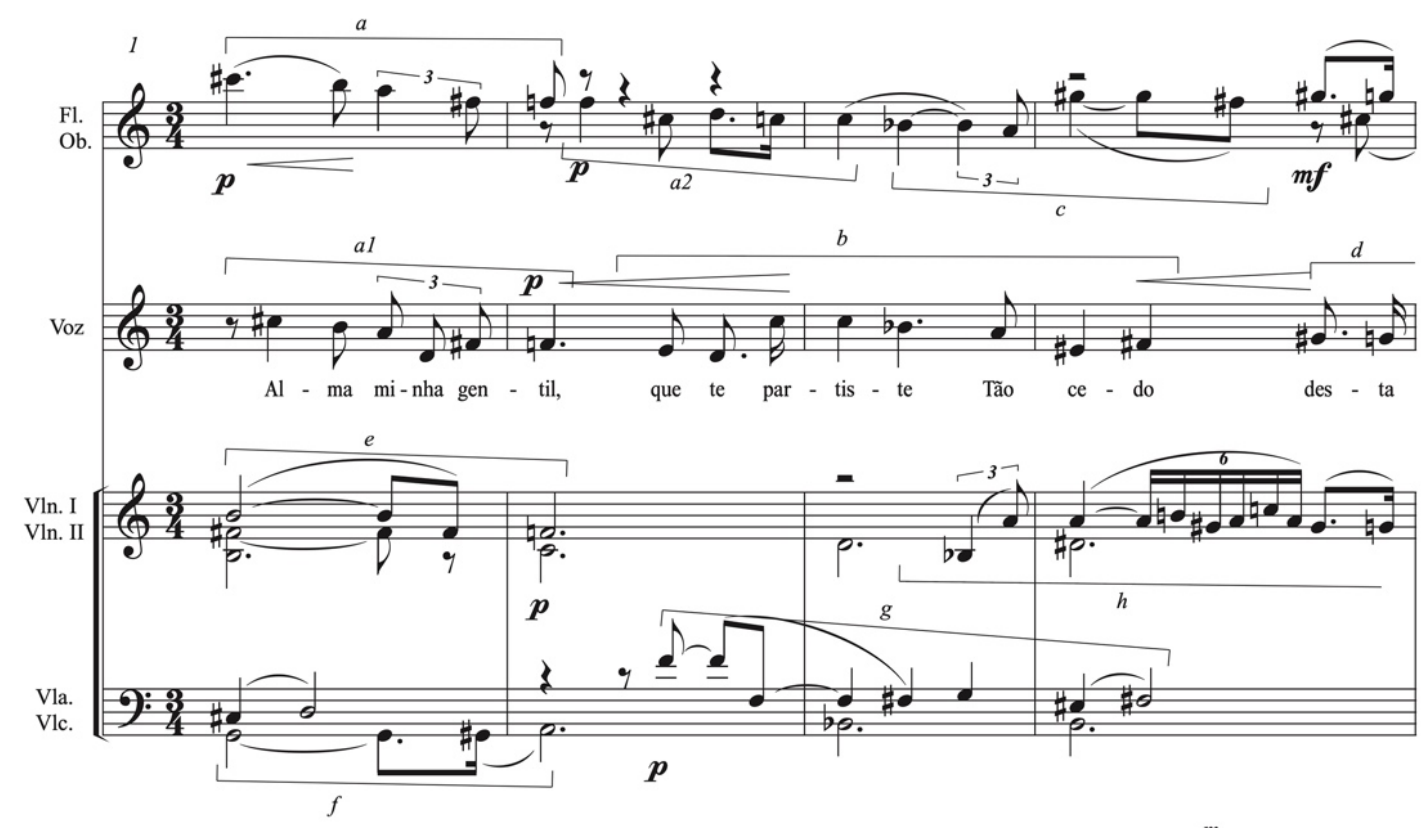




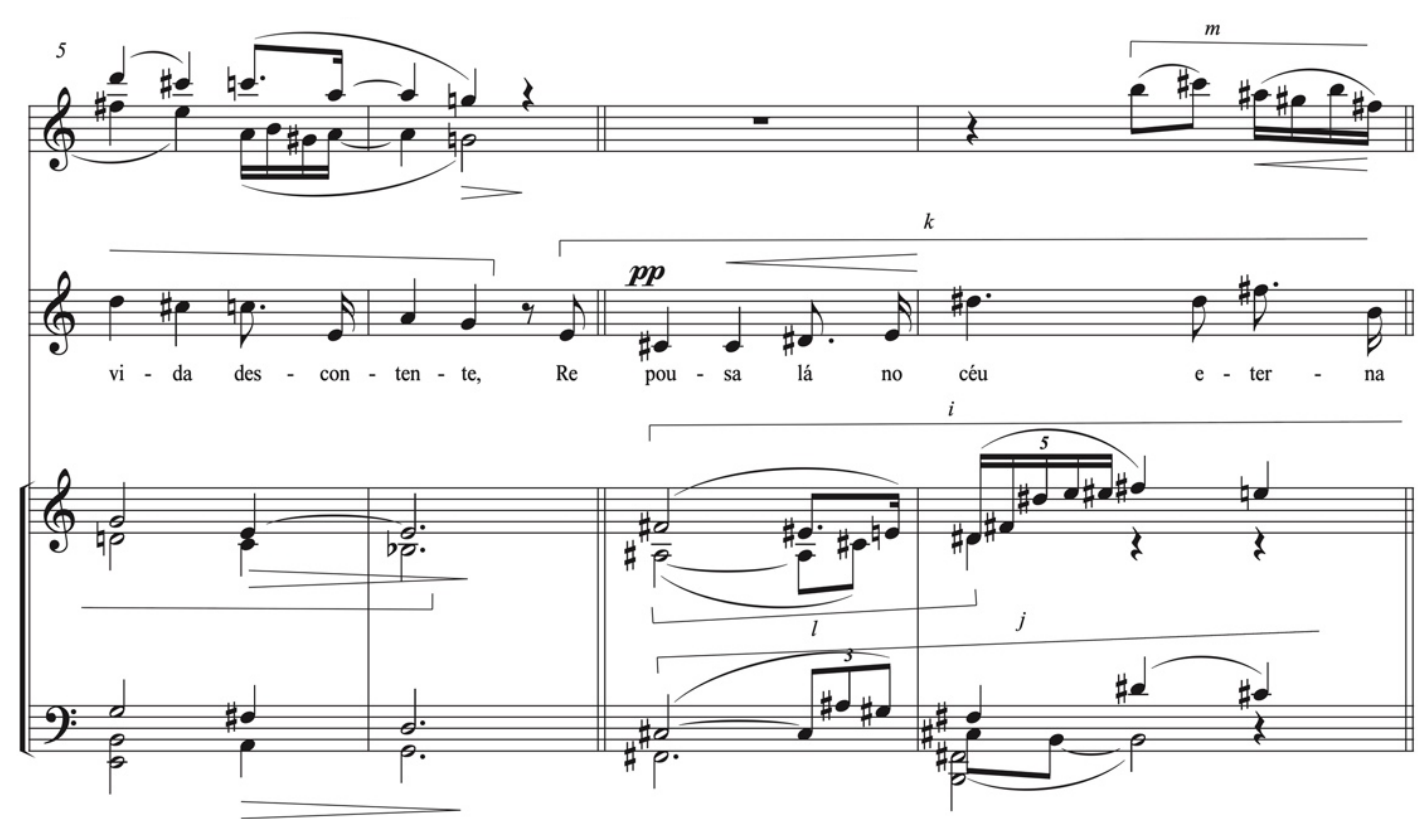

Exemplo 19: Excerto de G. Velasquez, Alma minha gentil, orquestração de Luciano Gallet.

\section{Observações finais}

As três abordagens motívico-temáticas descritas neste texto fazem parte da percepção musical e analítica de Arnold Schoenberg. Elas também são procedimentos de análise e de composição musical que fundamentam a estrutura motívica como um parâmetro importante dentro da teoria analítica e da noção de forma musical de Schoenberg.

A análise de repertório estranho ao cânone schoenberguiano é exemplificado pelas obras de Nepomuceno, Villa-Lobos e Velasquez, numa tentativa ainda que embrionária, de testar e validar as noções analíticas de desdobramento motívico e prosa musical de Schoenberg. Nas obras de Nepomuceno e Villa-Lobos há a clara inspiração de evocar um ambiente de música do período barroco; já na obra de Velasquez a intenção parece ser a de se aproximar de um tipo de linguagem musical da época do compositor. Nas outras obras discutidas, todas do cânone schoenberguiano, observa-se que é possível aprimorar o nosso entendimento através da leitura e abordagem motívicas e perceber como este parâmetro pode contribuir para a unidade destas obras, assim como para a identificação de estilo, seja ele relacionado ao período barroco, clássico, romântico ou atonal livre. 


\section{Referências}

1. Auner, Joseph. 2003. A Schoenberg Reader: Documents of a Life. New Haven: Yale University Press.

2. Bent, Ian (Ed.). 1994. Music Analysis in the Nineteenth Century. Volume I: Fugue, Form and Style. Cambridge: Cambridge University Press.

3. Berg, Alban, 1965. Why Is Schönberg's Music so Difficult to Understand. In Reich, Willi. In The Life and Work of Alban Berg, 189-204. London: Thames and Hudson.

4. Brinkmann, Reinhold. 2004. A 'Last Giant in Music': Thoughts on Max Reger in the Twentieth Century. Musical Quarterly 87, n. 4, p. 631-659.

5. Busoni, Ferruccio. 1987. Selected Letters. Trad. Antony Beaumont. London: Faber \& Faber.

6. Coelho de Souza, Rodolfo. 2006. Aspectos de Modernidade na Musica de Nepomuceno relacionados ao projeto de tradução do Harmonielehre de Schoenberg. Em Pauta, v. 17, n. 29, p. 63-81.

7. Cone, Edward T. 1989. Music: A View from Delft. Ed. Robert P Morgan. Chicago: University of Chicago Press.

8. Dahlhaus, Carl. 1975. Some Models of Unity in Musical Form. Journal of Music Theory, v. 19, n. 1, p. 2-30.

9. Dahlhaus, Carl. 1987. Schoenberg and The New Music. Trad. Derrick Puffet e Alfred Clayton. Cambridge: Cambridge University Press.

10. __. 1991. Ludwig van Beethoven, Approaches to His Music. Trad. Mary Whittall. Oxford: Oxford University Press.

11. Deathridge, John e Carl Dahlhaus. 1984. The New Grove - Wagner. New York: W. W. Norton \& CO.

12. Dudeque, Norton. 1999. Schoenberg's Gedanke Manuscript. British Postgraduate Musicology, v. 3, p. 44-49.

13. __ 2003. Variação progressiva como um processo gradual no primeiro movimento do quarteto 'A Dissonância', k. 465, de Mozart." Per Musi, v. 8, p. 41-56.

14. _. 2005. Music Theory and Analysis in the Writings of Arnold Schoenberg (18741951). Aldershot: Ashgate.

15. __ 2005. Aspectos do academicismo germânico no primeiro movimento do Quarteto n. 3 de Alberto Nepomuceno. Ictus v. 6, p. 211-232. 
MUSICA THEORICA Revista da Associação Brasileira de Teoria e Análise Musical 2020, v. 5, n. 2, p. 165-206 - Journal of the Brazilian Society for Music

16. Frisch, Walter. 1984. Brahms and the Principle of Developing Variation. Berkeley: University of California Press.

17. Grey, Thomas. 1995a. Um Glossário Wagneriano. In Wagner - Um Compêndio. Rio de Janeiro: Jorge Zahar Editor, p. 254-270.

18. Grey, Thomas. 1995b. Wagner's Musical Prose - Texts and Contexts. Cambridge: Cambridge University Press.

19. Haas, Michael. 2013. Forbidden Music The Jewish Composers Banned by the Nazis. New Haven: Yale University Press.

20. Haimo, Ethan. 1997. Schoenberg and the Origins of Atonality. In Constructive Dissonance, Arnold Schoenberg and the Transformations of Twentieth-Century Culture, ed. Juliane Brand and Christopher Hailey. Berkeley: University of California Press, p. 71-86.

21. __ 2006. Schoenberg's transformation of musical language. Cambridge: Cambridge University Press.

22. Harrison, Daniel. 2004. Max Reger Introduces Atonal Expressionism. Musical Quarterly, v. 87, no. 4, p. 660-680.

23. Lichtenthal, Peter. 1826. Dizionario e Bibliografia Della Musica. Milano: Per Antonio Fontana.

24. MacDonald, Malcolm. 2011. Schoenberg.Oxford: Oxford University Press.

25. Marx, Adolf B. 1852. The School of Musical Composition, Practical and Theoretical. London: Robert Cocks.

26. __. 1997. Musical Form in the Age of Beethoven - Selected Writings on Theory and Method. Ed. e Trad. Scott Burnham. Cambridge: Cambridge University Press.

27. Nelson, Robert U. 1948. The Technique of Variation - A Study of the Instrumental Variation from Antonio de Cabezón to Max Reger. Berkeley: University of California Press.

28. Samson, Jim. 1977. Music in Transition: A Study of Tonal Expansion and Atonality, 1900-1920. London: Dent.

29. Schoenberg, Arnold. 1949. Form in Music. Vienna: Arnold Schoenberg Center. Manuscrito T51.17.

30. _. 1975. Style and Idea, Selected Writings of Arnold Schoenberg. Ed. Leonard Stein. London: Faber \& Faber.

31. _. 1991. Fundamentos Da Composição Musical. Trad. Eduardo Seincman. São Paulo: Edusp. 
32. __. 1994. Coherence, Counterpoint, Instrumentation, Instruction in Form. Ed. Severine Neff. Trad. Charlotte M Cross e Severine Neff. Lincoln: University of Nebraska Press.

33. __. 1995. The Musical Idea and the Logic, Technique, and Art of Its Presentation. Ed. e Trad. Patricia Carpenter e Severine Neff. New York: Columbia University Press.

34. __. 2016. Schoenberg's Program Notes and Music Analysis. Ed. J. Daniel Jenkins. Oxford: Oxford University Press.

35. Simms, Bryan R. 2000. The Atonal Music of Arnold Schoenberg 1908-1923. Oxford: Oxford University Press.

36. Stein, Erwin. 1953. Orpheus in New Guises. London: Rockliff Publishing CO.

37. Tovey, Donald F. 1944. Essays in Musical Analysis - Chamber Music. London: Humphrey Milford and Oxford University Press. 